\title{
RNA-Seq analysis of European sea bass (Dicentrarchus labrax L.) infected with nodavirus reveals powerful modulation of the stress response
}

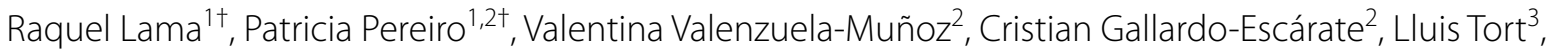
Antonio Figueras ${ }^{1}$ and Beatriz Novoa ${ }^{*}$ (D)

\begin{abstract}
Nodavirus, or nervous necrosis virus (NNV), is the causative agent of viral encephalopathy and retinopathy (VER), a severe disease affecting numerous fish species worldwide. European sea bass, a cultured species of great economic importance, is highly susceptible to the disease. To better understand the response of this organism to NNV, we conducted RNA-Seq analysis of the brain and head kidney from experimentally infected and uninfected sea bass juveniles at 24 and 72 hours post-infection (hpi). Contrary to what was expected, we observed modest modulation of immune-related genes in the brain, the target organ of this virus, and some of these genes were even downregulated. However, genes involved in the stress response showed extremely high modulation. Accordingly, the genes encoding the enzymes implicated in the synthesis of cortisol were almost the only overexpressed genes in the head kidney at $24 \mathrm{hpi}$. This stress response was attenuated after $72 \mathrm{~h}$ in both tissues, and a progressive immune response against the virus was mounted. Moreover, experiments were conducted to determine how stress activation could impact NNV replication. Our results show the complex interplay between viral activity, the stress reaction and the immune response.
\end{abstract}

\section{Introduction}

European sea bass (Dicentrarchus labrax L.) is a very valuable fish species in Mediterranean countries, and it is currently one of the main cultured fish species in Europe [1]. However, different infectious diseases can affect its production and cause important economic impacts in the aquaculture industry. One of the most significant diseases affecting D. labrax is viral encephalopathy and retinopathy (VER), which is characterized by severe damage to nervous tissues [2]. The causative agent of this

\footnotetext{
*Correspondence: beatriznovoa@iim.csic.es

${ }^{\dagger}$ Raquel Lama and Patricia Pereiro equally contributed to this work

1 Institute of Marine Research (IIM), National Research Council (CSIC), Eduardo Cabello, 6, 36208 Vigo, Spain

Full list of author information is available at the end of the article
}

disease is nervous necrosis virus (NNV), or nodavirus, belonging to family Nodaviridae, genus Betanodavirus. $\mathrm{NNV}$ is a naked, icosahedral, single-stranded, positivesense RNA virus [2]. The Betanodavirus genus is composed of 4 genotypes that infect different animal species [3], among which European sea bass seems to be mainly affected by the red-spotted grouper nervous necrosis virus (RGNNV) genotype [2, 4]. Due to its virulence and rapid spreading, it is associated with high mortality rates, reaching $100 \%$ in many cases, and although this disease mostly affects juveniles, it has also been detected in adult animals $[2,4]$. Because of its neurotropic nature, NNV mainly affects the brain and retina of infected fish. When the nervous system of an individual is affected, it manifests very specific symptoms, such as erratic swimming 
in descending circles, which can cause curvature of the dorsal spine, and other less specific symptoms (exophthalmia, bloated abdomen and anorexia).

Bioinformatic tools allow the in-depth study of the interactions between an infected organism and its pathogen. Several studies have used high-throughput RNA sequencing (RNA-Seq) to understand the effects of nodavirus via the transcriptome profiling of in vitroinfected cells. Such investigations have been performed in grouper kidney cells (GK cell line) [5], Asian sea bass epithelial cells (SB cell line) [6], European sea bass leukocytes [7], striped snakehead fish cells (SSN-1 cell line) [8] and European sea bass brain cells (DLB-1 cell line) [9]. The in vivo effect of NNV has also been analysed by RNA-Seq in the brain of sevenband grouper [10], pooled brain/eye and head kidney samples from Senegalese sole [11], the brain of Malabar grouper [12], and the liver, spleen and kidney of Epinephelus moara [13]. However, the in vivo response of European sea bass remains almost completely unexplored, and only a small number of publications have reported the modulation or involvement of immune factors in different tissues of D. labrax infected with NNV [14-22]. Therefore, the aim of this work was to analyse the complete transcriptome response of European sea bass to nodavirus infection. As the materials for this study, we selected the main target organ of this virus, the brain, as well as the head kidney because it plays crucial roles in the organization of both immune and stress responses. Interestingly, the induction of immune genes was practically undetectable, but we observed strong modulation of genes related to the hypothalamic-pituitary-interrenal (HPI) axis. Although numerous publications reported the effect of a variety of stressors in the susceptibility to diseases and their impact on different immune parameters [23], the stress response induced by pathogens remains practically unexplored in fish. However, pathogens are considered as an important environmental biotic stressor for plants and animals. This is the first time that RNA-Seq analysis has shown an interaction between neuroendocrine pathways and the immune system through the HPI axis during nodavirus infection.

\section{Materials and methods}

\section{Fish and virus}

Healthy juvenile specimens of European sea bass (Dicentrarchus labrax L.) were obtained from the facilities of the Estación de Ciencias Mariñas de Toralla (ECIMAT, Universidad de Vigo, Spain) (average body weight of $\sim 70 \mathrm{~g}$ ) or from the Naturix Cantabria hatchery (Cantabria, Spain) (average body weight of $\sim 10$ or $\sim 50 \mathrm{~g}$ ). Prior to the experiments, the fish were acclimatized to the laboratory conditions for 2 weeks; they were maintained in 500-litre fibreglass tanks with a re-circulating saline-water system (total salinity approximately $35 \mathrm{~g} / \mathrm{L}$ ) under a light-dark cycle of $12: 12 \mathrm{~h}$ at $20-22{ }^{\circ} \mathrm{C}$ and were fed daily with a commercial diet. The animals were euthanized via an MS-222 overdose. All the experimental procedures were reviewed and approved by the CSIC National Committee on Bioethics under approval number ES360570202001/17/FUN.01/INM06/BNG.

The viral strain $475-9 / 99$, belonging to the RGNNV genotype, was provided by the Institute Zooprofilattico delle Venize (Italy) after isolation from diseased sea bass [24]. The snakehead-fish cell line SSN-1 (ECACC 96082808) was grown at $25^{\circ} \mathrm{C}$ in Leibovitz's L15-medium (Gibco, Carlsbad, CA, USA) supplemented with 10\% heat-inactivated foetal bovine serum (FBS) (Gibco), 1\% L-glutamine (Gibco) and a $1 \%$ penicillin/streptomycin solution (Invitrogen). The virus was propagated in the SSN-1 cell line in the medium described above supplemented with $2 \% \mathrm{FBS}$, with incubation at $25{ }^{\circ} \mathrm{C}$ until the cytopathic effect was extensive. The supernatants were harvested and centrifuged to eliminate cell debris. Clarified supernatants were used in all infections. The viral titre, expressed as $\mathrm{TCID}_{50} / \mathrm{mL}$ (tissue culture infectious dose infecting $50 \%$ of inoculated cultures), was determined in 96-well plates according to the endpoint titration procedure [25].

\section{Fish infection and sampling for RNA-Seq}

Sedated specimens of European sea bass $(\sim 70 \mathrm{~g})$ were intramuscularly (i.m.) injected with $100 \mu \mathrm{L}$ of SSN-1 culture medium (control) or with culture medium containing NNV at $10^{6} \mathrm{TCID}_{50} / \mathrm{mL}$ (infected). A total of 9 fish per condition were sampled at 24 and $72 \mathrm{hpi}$. The same quantity of tissue from 3 animals was pooled, performing 3 biological replicates ( 3 fish/replicate) per tissue at each sampling point. The brain and head kidney were harvested under RNase-free conditions and stored at $-80^{\circ} \mathrm{C}$ until RNA isolation. In parallel, the effect of the viral challenge in the survival was analysed to confirm the virulence of the NNV in those animals sampled for the RNA-Seq analysis. For this, ten animals were inoculated with NNV or SSN-1 culture medium as mentioned above, and mortality was recorded during the next 2 weeks.

\section{RNA isolation and high-throughput transcriptome sequencing}

RNA extraction was performed with the Maxwell 16 LEV simply RNA tissue kit (Promega). The RNA concentration and purity were measured with a spectrophotometer (ND-1000; Nanodrop Technologies Inc., Wilmington, DE, USA), and RNA integrity was analysed in an Agilent 2100 Bioanalyzer (Agilent Technologies Inc., Santa Clara, CA, USA) according to the manufacturer's instructions. 
All the samples showed an RNA Integrity Number (RIN) over 8.0 and were therefore used for Illumina library preparation. Double-stranded cDNA libraries were constructed using the TruSeq RNA Sample Preparation Kit v2 (Illumina, San Diego, CA, USA), and sequencing was performed using Illumina HiSeq 4000 technology at Macrogen Inc., Korea (Seoul, Republic of Korea). The read sequences were deposited in the Sequence Read Archive (SRA) under accession number PRJNA589774.

Raw data cleaning, de novo assembly and gene annotation CLC Genomics Workbench v. 11.0.2 (CLC Bio, Aarhus, Denmark) was used for filtration and assembly and to perform the RNA-Seq and statistical analyses. Prior to assembly, the raw data from each sample were trimmed to remove adapter sequences and low-quality reads (quality score limit 0.05 ). All the high-quality reads were de novo assembled in a unique file using default parameters (mismatch cost $=2$, insert cost $=3$, minimum contig length $=200 \mathrm{bp}$, and similarity $=0.8$ ). The contigs yielded by this assembly were annotated with the Blast2GO program against the UniProtKB/SwissProt database with a cutoff E-value of $1 \mathrm{E}-03$.

\section{RNA-Seq analysis}

The transcriptome database generated for European sea bass was used as a reference for the RNA-Seq analyses (mismatches $=2$, length fraction $=0.8$, similarity fraction $=0.8$ ). Expression levels were calculated as transcripts per million (TPM) values. To determine statistically significant differences, a proportion-based statistical analysis was conducted using Baggerly's test and adjusting $p$-values by the false discovery rate (FDR) correction. Contigs showing a fold change $>2$ in the absolute value in relation to the control group and an FDR $<0.05$ were selected as differentially expressed genes (DEGs). Heat maps were constructed by plotting the $\log _{2}$ values of the normalized TPM values and were hierarchically clustered by estimating Manhattan distances with an average linkage criterion. Finally, functional annotation was performed at the online site DAVID 6.8 to conduct Gene Ontology (GO) enrichment and KEGG pathway analyses using the UniProtIDs of our DEG lists. For the GO and KEGG analyses, a $p<0.05$ was employed.

\section{NNV detection and RNA-Seq validation by quantitative PCR (qPCR)}

CDNA synthesis from the sequenced samples was performed with the NZY First-Strand CDNA Synthesis Kit (NZYtech, Lisbon, Portugal) using $0.1 \mu \mathrm{g}$ of total RNA. The qPCR assays were performed using specific primers, and their efficiencies were previously tested according to the method described by Pfaffl [26]. Individual
qPCR assays were conducted in a $25-\mu \mathrm{L}$ reaction volume including $12.5 \mu \mathrm{L}$ of SYBR GREEN PCR Master Mix (Applied Biosystems, Foster City, CA, USA), $10.5 \mu \mathrm{L}$ of ultrapure water (Sigma-Aldrich, St. Louis, MO, USA), $0.5 \mu \mathrm{L}$ of each specific primer $(10 \mu \mathrm{M})$ and $1 \mu \mathrm{L}$ of cDNA template. All reactions were performed in technical triplicates in a 7300 Real-Time PCR System thermocycler (Applied Biosystems) with an initial denaturation step $\left(95^{\circ} \mathrm{C}, 10 \mathrm{~min}\right.$ ), followed by 40 cycles of a denaturation step $\left(95{ }^{\circ} \mathrm{C}, 15 \mathrm{~s}\right)$ and a singly hybridization-elongation step $\left(60{ }^{\circ} \mathrm{C}, 30 \mathrm{~s}\right)$. Relative gene expression was calculated via the Pfaffl method [26] and using $18 S$ ribosomal RNA (18S) as a reference gene. Fold units were calculated by dividing the normalized expression values of the different samples by the normalized expression values obtained in the controls.

To detect viral replication, a 203-bp PCR product from the NNV coat protein gene (RNA2) was chosen for its specificity and the absence of PCR artefacts or primer dimers [27].

Twelve genes that were significantly modulated in the brain or head kidney were chosen for the validation of the RNA-Seq results. The sequences of the primers used for NNV detection and RNA-Seq validation are listed in Additional file 1. Additionally, a biological validation was conducted in an independent experiment. For this, ten sea bass $(\sim 50 \mathrm{~g})$ were i.m. injected with $100 \mu \mathrm{L}$ of SSN-1 culture medium (control) or with culture medium containing NNV at $10^{6} \mathrm{TCID}_{50} / \mathrm{mL}$ (infected). Five individual brain samples were taken at 24 and $72 \mathrm{hpi}$. Three genes that were significantly modulated in the RNA-Seq data were selected for qPCR analysis.

\section{Cortisol implants and nodavirus challenge}

A cortisol implant was prepared by dissolving cortisol (Sigma-Aldrich) in coconut oil (Sigma-Aldrich) at a final concentration of $50 \mu \mathrm{g}$ cortisol/g body weight [28]. Juvenile sea bass $(\sim 10 \mathrm{~g})$ were anaesthetized, intraperinoteally (i.p.) injected with $100 \mu \mathrm{L}$ of the cortisol implant or the vehicle alone (coconut oil), and them i.m. injected with $100 \mu \mathrm{L}$ of an NNV suspension at $2 \times 10^{4} \mathrm{TCID}_{50} / \mathrm{mL}$ (infected) or the culture medium alone (control). The mortality of each treatment (two replicates of 20 fish each) was recorded.

In parallel, forty fish were divided into 4 tanks (10 fish/ tank) and each group was inoculated as mentioned above for the survival experiment. Brain samples were collected at 24 and $72 \mathrm{hpi}$ from each group ( $n=5$ individuals). The total brain was homogenized and half of the tissue was used for RNA isolation and the other half for protein extraction. RNA was used to analyse by qPCR the replication of the virus and the expression of two genes that were significantly modulated according to the RNA-Seq 
results: the immune gene encoding IgM (ighm), and the gene encoding the stress hormone prolactin $(\mathrm{prl})$.

The remaining tissue was used for IgM detection via an enzyme-linked immunosorbent assay (ELISA). Frozen samples were homogenized in $400 \mu \mathrm{L}$ of buffer containing $150 \mathrm{mM} \mathrm{NaCl}, 10 \mathrm{mM}$ Tris-HCl, $1 \mathrm{mM}$ EGTA, $1 \mathrm{mM}$ EDTA (pH 7.4), 1\% Triton X-100, 0.5\% NP40-IGEPAL, $1 \times$ Halt phosphatase inhibitor cocktail (Sigma-Aldrich) and $1 \times$ protease inhibitor cocktail (Sigma-Aldrich). The tubes were kept on ice throughout the process to prevent protein denaturation. The homogenates were centrifuged at $1000 \mathrm{~g}$ for $15 \mathrm{~min}$ at $4{ }^{\circ} \mathrm{C}$, and the supernatants were centrifuged again at $20000 \mathrm{~g}$ for $30 \mathrm{~min}$ at $4{ }^{\circ} \mathrm{C}$. The resulting supernatants were recovered and stored at $-80^{\circ} \mathrm{C}$. The concentration of protein in each sample was determined using a NanoDrop ND-1000 spectrophotometer. Protein extracts were diluted in $20 \mathrm{mM}$ Tris $-\mathrm{HCl}$ (pH 4) at a proportion of $1 \mu \mathrm{g}$ per $50 \mu \mathrm{L}$, and this volume was dispensed into each well of a 96-well flat-bottom high-binding plate (Costar, Cambridge, MA, USA), which was then incubated overnight at $37^{\circ} \mathrm{C}$. A $100-\mu \mathrm{L}$ volume of an $8 \%$ non-fat dry milk solution in each well was used for blocking at room temperature (RT) for $4 \mathrm{~h}$. Then, the wells were washed three times with distilled water. For the detection of the protein, $50 \mu \mathrm{L}$ of a solution of the anti-IgM monoclonal antibody (Aquatic Diagnostics Ltd., Stirling, Scotland, UK) diluted 1:33 in ELISA buffer (0.5\% BSA, $0.01 \%$ Tween $20,0.005 \%$ phenol red and $10 \%$ PBS in distilled water; $\mathrm{pH} 7$ ) was added to the wells, followed by incubation for $2 \mathrm{~h}$ at RT and then washing three times with distilled water. The same volume of ELISA buffer alone at the same concentration was used as a negative control. A $50-\mu \mathrm{L}$ volume per well of a goat antimouse IgG antibody labelled with horseradish peroxidase (HRP) (Sigma-Aldrich) diluted 1:500 in ELISA buffer was applied as the secondary antibody for the detection of the specific IgM-primary antibody interaction, followed by incubation for $45 \mathrm{~min}$ at RT. After three washes, $100 \mu \mathrm{L}$ of the 1-Step Ultra TMB-ELISA solution (Thermo Scientific, Waltham, MA, USA) was added to each well. The reaction was stopped with $2 \mathrm{~N} \mathrm{H}_{2} \mathrm{SO}_{4}$, and the optical density was measured at $450 \mathrm{~nm}$ with a spectrophotometer (Labsystems iEMS Reader MF). The intensity of the control signal was subtracted from the intensity of the signal obtained with the anti-IgM antibody. These values were directly proportional to the amount of IgM protein present in each well.

\section{Respiratory burst activity determined by chemiluminescence assays}

To verify the capacity of the infected cells to produce reactive oxygen species (ROS), we analysed the burst activity of kidney leukocytes during in vitro and in vivo infections. For the in vitro assay, the head kidneys were collected under sterile conditions in Leibovitz's medium $1 \times($ L15) and subjected to forced passage through a $100 \mu \mathrm{m}$ nylon mesh. The obtained head kidney cell suspensions were layered over a 51\% Percoll (GE Healthcare, Chicago, IL, USA) density gradient and centrifuged at $400 \mathrm{~g}$ for $30 \mathrm{~min}$ at $4{ }^{\circ} \mathrm{C}$. After centrifugation, the band of leucocytes above the Percoll-medium interface was collected with a Pasteur pipette, washed twice with L15 and centrifuged at $400 \mathrm{~g}$ for $10 \mathrm{~min}$ at $4{ }^{\circ} \mathrm{C}$. The cell pellet was resuspended in L15 supplemented as the SSN-1 medium. The cells were counted and adjusted to a concentration of $10^{6}$ cells $/ \mathrm{mL}$. The cell suspensions were distributed in 96-well opaque white plates with a flat bottom and low evaporation lid (Falcon), and infected (or not) with NNV $\left(10^{4} \mathrm{TCID}_{50} / \mathrm{mL}\right)$ for $1,24,48$ and $72 \mathrm{~h}$ before ROS production measurement. For the in vivo assay, animals $(\sim 10 \mathrm{~g})$ were i.m. infected (or not) with NNV $\left(10^{4} \mathrm{TCID}_{50} / \mathrm{mL}\right)$ and at 1 and 5 days post-infection (dpi), head kidney samples were taken, and leukocytes were collected as described above, then plated in opaque white plates.

The emission of relative luminescence units (RLU) was determined after the stimulation of the cells with phorbol myristate acetate (PMA, Sigma-Aldrich) and amplified by the addition of 5-amino-2,3-dihydro-1,4-phthalazinedione (Luminol, Sigma-Aldrich). A stock solution of $0.1 \mathrm{M}$ luminol was prepared in dimethyl sulfoxide (DMSO, Sigma-Aldrich) just before use. Luminol was diluted in phosphate-buffered saline (PBS, Gibco) to obtain a working solution with a final concentration of $10-4 \mathrm{M}$. The PMA stock ( $1 \mathrm{mg} / \mathrm{mL}$ in DMSO) was also diluted in the luminol working solution to obtain a final concentration of $1 \mu \mathrm{g} / \mathrm{mL}$. The working solutions of luminol either alone or in combination with PMA were added to the wells, and the generation of chemiluminescence was measured after $5 \mathrm{~min}$ in a luminometer (Fluoroskan Ascent, Labsystems, Vantaa, Finland). Four individual biological replicates and triplicate wells were assayed.

\section{Inactivation of NNV using hydrogen peroxide}

Hydrogen peroxide $\left(\mathrm{H}_{2} \mathrm{O}_{2}\right)$ has been used to study the effect of ROS produced during viral infection on nodavirus replication. A 30\% stock solution of $\mathrm{H}_{2} \mathrm{O}_{2}$ (Perhydrol; Merck, Darmstadt, Germany) was sterilized by filtration through a $0.22 \mu \mathrm{m}$-pore filter and kept in a dark sealed container. The viral suspension $\left(10^{4} \mathrm{TCID}_{50} / \mathrm{mL}\right)$ was treated with the $\mathrm{H}_{2} \mathrm{O}_{2}$ solution at a final concentration of $3 \%$ and incubated for 5 or $24 \mathrm{~h}$ at $4{ }^{\circ} \mathrm{C}$. To stop the reaction and remove residual $\mathrm{H}_{2} \mathrm{O}_{2}$, the viral suspensions were treated twice with $12.5 \mathrm{U} / \mathrm{mL}$ of catalase from bovine liver (Sigma-Aldrich) for $10 \mathrm{~min}$ at room temperature. Viral suspensions without $\mathrm{H}_{2} \mathrm{O}_{2}$ treatment 
were incubated under the same conditions and served as a control for the infection, and aliquots of $\mathrm{H}_{2} \mathrm{O}_{2}$-catalase treated medium were also included as a control for the treatment. Then, SSN-1 cells seeded in 24-well plates were inoculated with these suspensions (4 wells per condition) and incubated at $25^{\circ} \mathrm{C}$ for $72 \mathrm{~h}$. After this period, viral replication was analysed by qPCR.

\section{Intracellular calcium measurement with FLUO-4 AM}

For in vitro experiments, SSN-1 cells were distributed in 24-well plates, infected with NNV $\left(10^{4} \mathrm{TCID}_{50} / \mathrm{mL}\right)$ and incubated at $25{ }^{\circ} \mathrm{C}$ for 24,72 and $96 \mathrm{~h}$. Noninfected controls were also included. For in vivo experiments, fish were i.m. injected with $\mathrm{NNV}\left(10^{4} \mathrm{TCID}_{50} / \mathrm{mL}\right)$ or culture medium, and at 1 and $5 \mathrm{dpi}$, primary cell cultures of the brain were obtained (4 biological replicates per condition and sampling point). The entire brain was sampled; the meninges were completely removed by dissection; and the brain was finally collected in Hanks' Balanced Salt Solution without calcium chloride or magnesium sulphate (HBSS, Sigma-Aldrich), washed three times and subjected to forced passage through an $80 \mu \mathrm{m}$ nylon mesh. The obtained cell suspension was centrifuged at $300 \mathrm{~g}$ for $10 \mathrm{~min}$ at $4{ }^{\circ} \mathrm{C}$. The cell pellet was resuspended in Leibovitz's medium $1 \times(\mathrm{L} 15)$ supplemented as the SSN-1 medium. The brain cells were counted and adjusted to a concentration of $10^{6}$ cells $/ \mathrm{mL}$.

For both experiments cells were washed with PBS and loaded with $10 \mu \mathrm{L}$ of FLUO-4 AM (Sigma-Aldrich) diluted in L15 without phenol red (Sigma-Aldrich) to avoid interfering with the fluorescence of the probe. After an incubation period of $2.5 \mathrm{~h}$ at $25^{\circ} \mathrm{C}$, the cells were washed, followed by $45 \mathrm{~min}$ of de-esterification. The cells were then counted and resuspended at a concentration of $2 \times 10^{5}$ cells $/ \mathrm{mL}$ in L15 without phenol red. The cell suspensions were distributed in black 96-well plates (Cliniplate-Thermo Scientific, Waltham, MA, USA) to measure changes in fluorescence with an excitation wavelength of $485 \mathrm{~nm}$ and emission wavelength of $538 \mathrm{~nm}$ (Fluoroskan Ascent, Labsystems, Vantaa, Finland). Each sample was measured in triplicate.

\section{Cell treatment with calcium channel inhibitors and calcium chelators}

We used different inhibitors of cellular calcium channels and calcium chelators to study the effect of cytoplasmic calcium on NNV replication and ROS production. As inhibitors of calcium channels, we used thapsigargin (Tg; Sigma-Aldrich), which causes calcium release from the endoplasmic reticulum; carboxyamidotriazole (CAI; Sigma-Aldrich), which is an inhibitor of non-voltagedependent calcium entry and inhibits mitochondrial calcium import; nitrendipine (Sigma-Aldrich), a calcium entry blocker shown to inhibit the movement of calcium through L-type calcium channels; and verapamil hydrochloride (Sigma-Aldrich), which inhibits calcium movement across cell membranes, both inward and outward. As calcium chelators, we selected the intracellular calcium chelator BAPTA-AM (Sigma-Aldrich) and the extracellular calcium chelator EGTA (Sigma-Aldrich). The final concentrations used for the experiments were as follows: $\operatorname{Tg}(5 \mu \mathrm{M})$, CAI $(0.5 \mu \mathrm{M})$, nitrendipine $(0.5 \mu \mathrm{M})$, BAPTA-AM $(50 \mu \mathrm{M})$, and EGTA $(60 \mu \mathrm{M})$.

To analyse the effect of the changes in calcium homeostasis on NNV replication, SSN-1 cells were distributed in 24-well plates and pretreated for $2 \mathrm{~h}$ with the calcium chelators and pharmacological inhibitors, then washed twice with PBS and infected with NNV $\left(10^{4} \mathrm{TCID}_{50} / \mathrm{mL}\right)$ for $48 \mathrm{~h}$ at $25^{\circ} \mathrm{C}$. Viral replication was analysed by qPCR in 5 biological replicates per treatment.

To determine ROS production in the presence of the calcium chelators, primary cultures of head kidney leukocytes were pretreated for $2 \mathrm{~h}$ with the calcium chelators BAPTA-AM and EGTA, washed twice with PBS, and inoculated with NNV (infected) or control medium (control) for $1 \mathrm{~h}$. ROS production was measured as described above with 8 biological replicates and 3 technical replicates.

\section{Statistical analysis}

Kaplan-Meier survival curves were analysed with a logrank (Mantel-Cox) test. The correlation between the RNA-Seq and qPCR data was analysed by using Pearson's correlation coefficient. For the remaining experiments, the results were represented graphically as the mean + standard error of the mean (SEM), and significant differences were determined using Student's $t$-test. For the comparisons among different sampling points the significant differences were stablished using oneway ANOVA (poshoc Tukey's multiple comparison test). Statistically significant differences were indicated

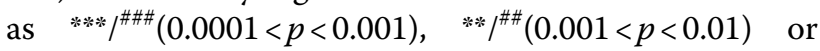
$* / \#(0.01<p<0.05)$.

\section{Results}

\section{Effects of NNV challenge in juvenile sea bass}

European sea bass challenged with NNV began to manifest clinical signs of infection at $8 \mathrm{dpi}$; these signs mainly consisted of erratic swimming behaviours, such as spiral or whirling swimming, belly-up floating, and laying down at rest (Additional file 2). After 12 days, the survival rate of the infected individuals was only $16.5 \%$ (Figure $1 \mathrm{~A}$ ). In parallel to this mortality assay, we collected brain and head kidney samples from infected and uninfected animals at 24 and $72 \mathrm{hpi}$, which were used for RNA-Seq analyses. NNV replication was confirmed by qPCR in 

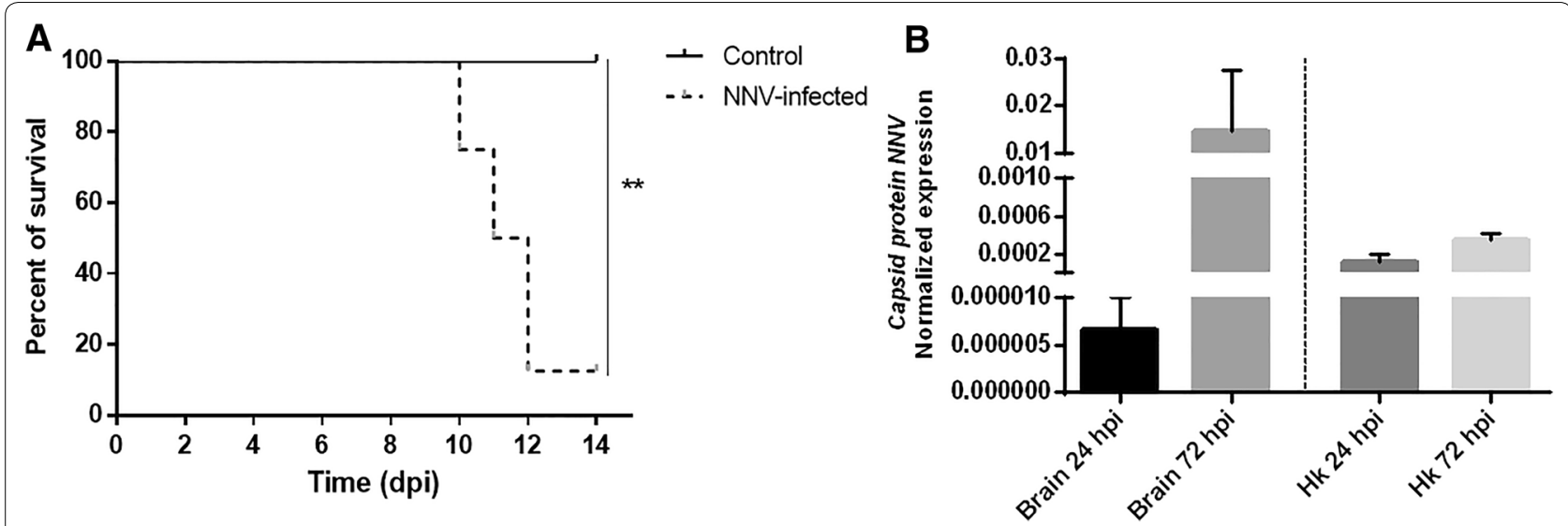

Figure 1 Effects of NNV intramuscular infection in juvenile D. labrax. A Kaplan-Meier survival of NNV-infected and uninfected fish. B Replication of NNV at 24 and 72 hpi in brain and head kidney samples. The level of viral replication was measured by qPCR amplification of the gene encoding the NNV capsid.

Table 1 Summary of Illumina sequencing, assembly and annotation.

\begin{tabular}{ll}
\hline Description & Value \\
\hline Raw data & \\
Reads per sample & 28044852.60 \\
Average lenght (bp) & 101 \\
Number of samples & 24 \\
De novo assembly & \\
Number of contigs & 347317 \\
Average length (bp) & 723 \\
N75 (bp) & 453 \\
N50 (bp) & 1088 \\
N25 (bp) & 2851 \\
UniprotKB/swiss-prot blast & \\
Successfully annotated contigs (\%) & 10.2 \\
\hline
\end{tabular}

these samples and, although statistically significant differences were not observed between 24 and $72 \mathrm{hpi}$, the viral replication tended to increase with time in the brain, whereas the uninfected control samples were negative for the detection of the virus (Figure 1B). As expected, higher replication levels were detected in the brain, which is the target tissue of NNV, after $72 \mathrm{~h}$.

\section{Transcriptome modulation in European sea bass after NNV infection}

A summary of the average reads per sample, assembly data and contig annotation is provided in Table 1. After adapter trimming and quality filtering of the raw data, an average of 28044852.6 high-quality reads per sample were obtained, with a mean length of $101 \mathrm{bp}$. These reads were de novo assembled and yielded a total of 347317 contigs. Among these contigs, $10.2 \%$ were successfully annotated against the UniProtKB/Swiss-Prot database with an E-value cutoff of 1E-03.

RNA-Seq analyses were conducted to evaluate transcriptome modulation in the brain and head kidney during infection with nodavirus. Using the obtained data, DEGs between the infected and uninfected fish were identified according to an $\mathrm{FC}>|2|$ and $\mathrm{FDR}<0.05$. As expected, due to the neurotropic nature of the virus, a greater number of DEGs were registered in the brain, which showed 4062 transcripts that were differentially regulated at $24 \mathrm{hpi}$ and 1478 at $72 \mathrm{hpi}$ (Figure 2A; Additional file 3 ). On the other hand, only 32 and 76 DEGs were registered in the head kidney at 24 and $72 \mathrm{hpi}$, respectively (Figure 2D; Additional file 4). Both the stacked column chart (Figure 2A) and the corresponding heat map (Figure 2B) showed that most of the transcripts that were significantly modulated in the brain at 24 hpi were inhibited by the viral challenge; however, the response seemed to be more equilibrated at $72 \mathrm{hpi}$ (Figures $2 \mathrm{~A}-\mathrm{C}$ ), which was also observed in the head kidney (Figures 2D-F).

GO enrichment analyses were carried out to explore the biological processes that were enriched during infection. In the brain, only four biological processes were significantly enriched at 24 hpi: "calcium ion transmembrane transport", "response to mechanical stimulus", "negative regulation of dendrite morphogenesis" and "positive regulation of plasminogen activation" (Figure 3A). However, although the number of DEGs in the brain was lower at $72 \mathrm{hpi}$, the number of enriched terms was 31 in this case, and many of them were related to ion transport and processes regulated by calcium or mediated by different neurotransmitters or their receptors (Figure 3B). In the case of the head kidney, enriched 


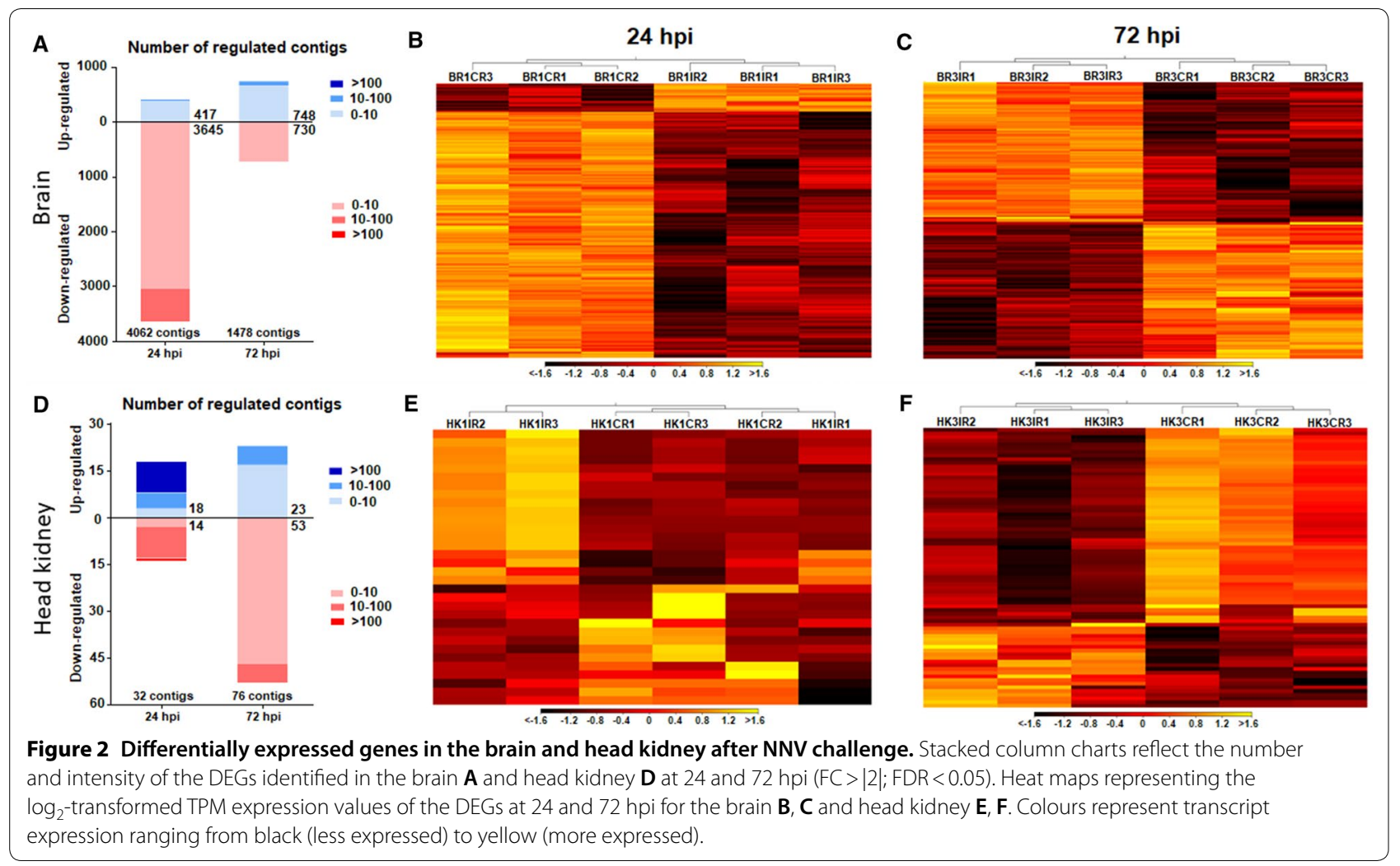

biological processes were only obtained at $24 \mathrm{hpi}$, with the terms "oxidation-reduction process", "glucocorticoid biosynthetic process" and "sterol metabolic process" being the most enriched (Figure 3C).

\section{Modulation of immune-related genes after NNV infection}

Whereas almost no typical immune genes seemed to be significantly modulated by viral challenge in the head kidney at the analysed sampling points, some of these genes were differentially expressed in the brain (Table 2). At $24 \mathrm{hpi}$, only 10 immune-related contigs were modulated by the infection, including the overexpression of a c-type lectin, the chemotaxin lect 2 and the nktr receptor of natural killer cells. Interestingly, three relevant immune genes were downregulated at this sampling point: the immunoglobulin mu chain $C$ region secreted form (ighm), the stimulator of interferon genes protein (sting) and the $N L R$ family CARD domain containing 3 (nlrc3). After $72 \mathrm{~h}$, the number of immune genes that were modulated by the infection was also low, with the only overexpressed genes being pentraxin 4 (ptx4), viperin or radical S-adenosyl methionine domain-containing protein 2 ( rsad), complement component $c 3$ (co3) and complement c1q tumour necrosis factor-related protein 1 (c1qt1) (Table 2).

\section{Nodavirus induces alterations in the HPI axis} HPI axis modulation in the brain

As reflected in the top 25 modulated contigs identified in the brain (Table 3), numerous genes encoding hormones involved in the HPI axis were greatly modulated after NNV infection. These genes corresponded to the pituitary hormones prolactin ( $p r l)$, somatolactin (sl), somatotropin (soma) or growth hormone (gh), gonadotropin (glha), thyrotropin (tsh) and pro-opiomelanocortin (pomc), the last of which encodes the precursor protein of adrenocorticotropic hormone $(\mathrm{ACTH})$. Interestingly, a Venn diagram of the DEGs identified in the brain at 24 and $72 \mathrm{hpi}$ revealed that among the 47 DEGs that were commonly modulated at both sampling points, there were 16 contigs that switched from being downregulated at 24 hpi to upregulated at $72 \mathrm{hpi}$ (Figure 4A). These genes included those encoding the pituitary hormones $\mathrm{prl}, \mathrm{gh}, \mathrm{glh}, \mathrm{tsh}$ and pomc (Figure 4B). Therefore, from 24 to $72 \mathrm{hpi}$, there was a complete shift in the expression of these HPI-related genes. On the other hand, only 2 common DEGs between 24 and 72 hpi showed a change from being upregulated at 24 to downregulated at $72 \mathrm{hpi}$, which corresponded to leukocyte cell-derived chemotaxin-2 (lect2) and the glutamate receptor ionotropic 


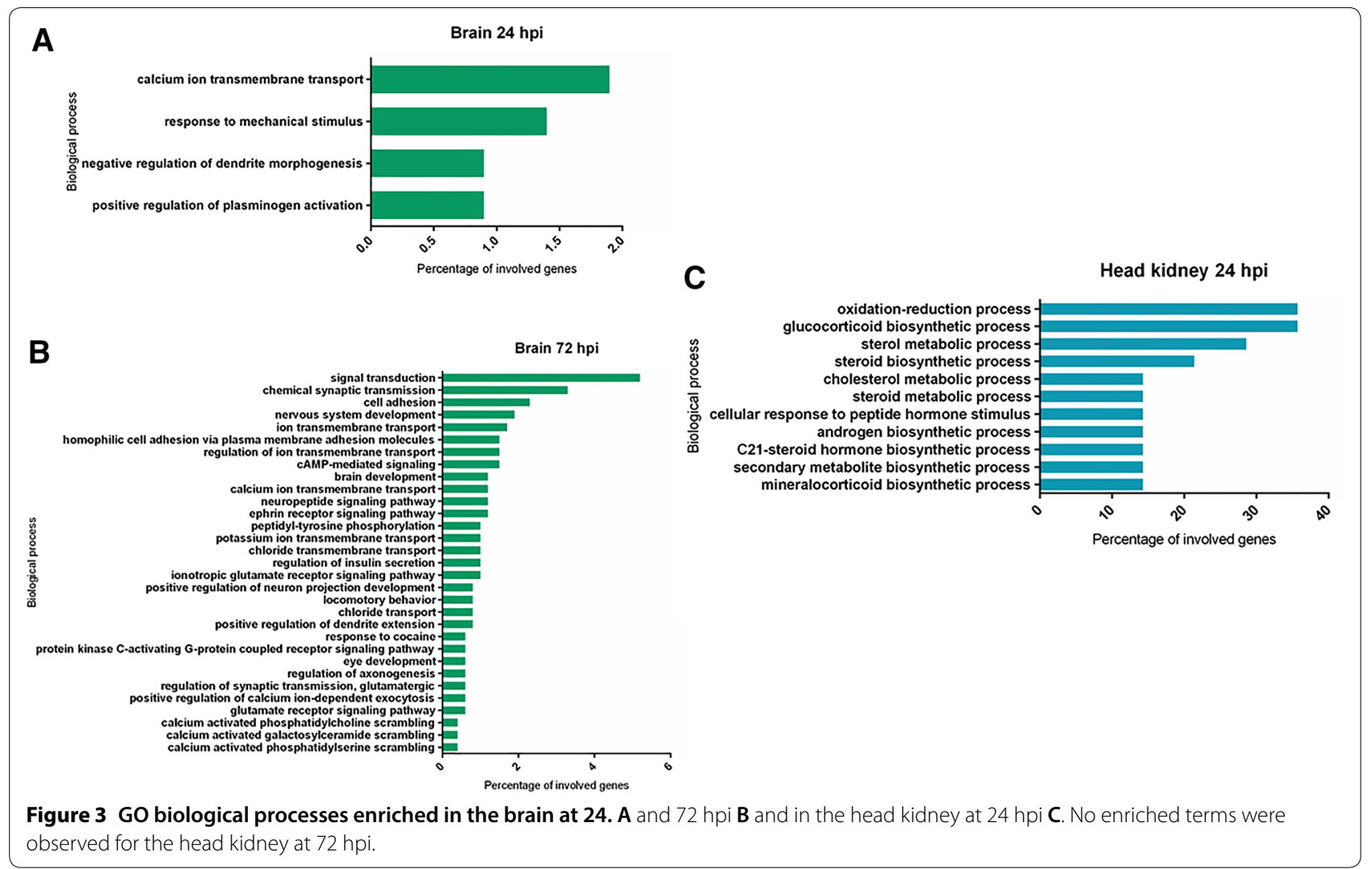

Table 2 Immune-related genes significantly modulated in the brain after NNV challenge.

\begin{tabular}{|c|c|c|}
\hline Gene Name & $24 \mathrm{hpi}$ & 72 hpi \\
\hline Leukocyte cell-derived chemotaxin 2 (LECT2) & 3.54 & -4.89 \\
\hline C-type lectin (TETN) & 3.85 & \\
\hline T-cell leukemia homeobox protein 3 (TLX3) & 2.47 & \\
\hline Platelet-derived growth factor receptor (PGFR) & 2.35 & 2.15 \\
\hline NK-tumor recognition protein (NKTR) & 2.14 & \\
\hline Eomesodermin (EOMES) & 2.06 & \\
\hline Probable ATP-dependent RNA helicase DDX17 (DDX17) & 2.01 & \\
\hline Ig mu chain $\mathrm{C}$ region secreted form (IGHM) & -2.91 & \\
\hline Stimulator of interferon genes protein (STING) & -4.13 & \\
\hline NLR family CARD domain containing 3 (NLRC3) & -8.7 & \\
\hline Pentraxin-4 (PTX4) & & 13.24 \\
\hline Radical S-adenosyl methionine domain-containing protein 2 (RSAD2) & & 6.25 \\
\hline Complement component C3 (CO3) & & 5.66 \\
\hline Complement C1q tumor necrosis factor-related protein 1 (C1QT1) & & 2.15 \\
\hline B-cell lymphoma/leukemia 11A (BC11A) & & -2.09 \\
\hline Semaphorin-4C (SEM4C) & & -2.12 \\
\hline Nitric oxide synthase, brain (NOS1) & & -2.39 \\
\hline E3 ubiquitin-protein ligase TRIM39 (TRIM39) & & -2.66 \\
\hline Platelet glycoprotein V (GPV) & & -3.52 \\
\hline Leukocyte cell-derived chemotaxin 1 (CNMD) & & -4.88 \\
\hline
\end{tabular}


Table 3 Top 25 up- and down-regulated DEGs in the brain at 24 and $72 \mathrm{hpi}$.

\begin{tabular}{|c|c|c|c|}
\hline \multicolumn{2}{|l|}{ Up } & \multicolumn{2}{|l|}{ Down } \\
\hline Blast2GO UniProt/SwissProt description & FC & Blast2GO UniProt/SwissProt description & FC \\
\hline \multicolumn{4}{|l|}{24 hpi } \\
\hline Hydroxytryptamine receptor 3E (5HT3E5) & 51.82 & Prolactin (PRL) & -101144.45 \\
\hline Bile acid-CoA:amino acid N-acyltransferase (BAAT) & 13.07 & Somatolactin (SL) & -13670.06 \\
\hline Actin-related protein $2 / 3$ complex subunit $1 \mathrm{~A}(\mathrm{ARC} 1 \mathrm{~A})$ & 12.76 & Somatotropin (SOMA)-growht hormone $(\mathrm{GH})$ & -2711.84 \\
\hline Collagen alpha- $1(\mathrm{X})$ chain (COAA1) & 10.87 & Gonadotropin subunit beta-2 (GTHB2) & -1896.99 \\
\hline B2 bradykinin receptor (BKRB2) & 7.36 & O-acyltransferase like protein (OACYL) & -377.22 \\
\hline Deoxyribonuclease-1 (DNAS1) & 6.95 & Pro-opiomelanocortin (POMC) & -349.84 \\
\hline Deoxyribonuclease-1 (DNAS1) & 6.48 & Serotransferrin-1 (STF) & -240.04 \\
\hline Alkaline phosphatase, tissue-nonspecific isozyme (PPBT) & 6.20 & Thyrotropin subunit beta (TSHB) & -172.68 \\
\hline Proline-rich basic protein 1 (PROB1) & 4.78 & Gonadotropin alpha chain (GLHA) & -71.08 \\
\hline Probable cysteine-tRNA ligase, mitochondrial (SYCM) & 4.68 & Transmembrane protein 130 (TM130) & -27.42 \\
\hline MAGUK p55 subfamily member 4 (MPP4) & 4.34 & $\begin{array}{l}\text { LINE-1 type transposase domain-containing protein } 1 \\
\text { (LITD1) }\end{array}$ & -18.39 \\
\hline Acidic repeat-containing protein (ACRC) & 4.20 & Pituitary-specific positive transcription factor 1 (PIT1) & -16.88 \\
\hline Gag-Pol polyprotein (POL) & 4.14 & Troponin T, fast skeletal muscle isoforms (TNNT3) & -16.50 \\
\hline MICAL-like protein 2 (MILK2) & 4.12 & Transcription factor COE1 (COE1) & -16.04 \\
\hline $\begin{array}{l}\text { Leucine-rich repeat and coiled-coil domain-containing } \\
\text { protein } 1 \text { (LRCC1) }\end{array}$ & 4.07 & Methylmalonyl-CoA mutase, mitochondrial (MUTA) & -15.94 \\
\hline Tetranectin (TETN) & 3.86 & Gonadotropin subunit beta-1 (GTHB1) & -12.59 \\
\hline ATP-binding cassette sub-family A member 1 (ABCA1) & 3.81 & LINE-1 reverse transcriptase homolog (LIN1) & -10.49 \\
\hline Oxysterol-binding protein-related protein 11 (OSB11) & 3.78 & Pituitary homeobox 3 (PITX3) & -10.15 \\
\hline DNA replication complex GINS protein PSF3 (PSF3) & 3.58 & $\begin{array}{l}\text { Myosin regulatory light chain 2, skeletal muscle isoform } \\
\text { type } 2 \text { (MLRS) }\end{array}$ & -9.10 \\
\hline Filamin-C (FLNC) & 3.57 & NLR family CARD domain containing 3 (NLRC3) & -8.70 \\
\hline Leukocyte cell-derived chemotaxin-2 (LECT2) & 3.55 & LINE-1 retrotransposable element ORF2 protein (LORF2) & -8.66 \\
\hline $\begin{array}{l}\text { Deoxynucleoside triphosphate triphosphohydrolase } \\
\text { SAMHD1 (SAMH1) }\end{array}$ & 3.50 & UPF0577 protein KIAA1324 (K1324) & -8.58 \\
\hline Protein largen (LARGN) & 3.41 & NADH dehydrogenase (NDUFA1) & -7.48 \\
\hline High affinity choline transporter 1 (SC5A7) & 3.37 & Regulator of rDNA transcription protein 15 (RRT15) & -7.20 \\
\hline Cathepsin D (CATD) & 3.36 & Fructose-bisphosphate aldolase A (ALDOA) & -6.90 \\
\hline \multicolumn{4}{|l|}{72 hpi } \\
\hline Prolactin (PRL) & 4713.60 & $\begin{array}{l}\text { Myosin regulatory light chain 2, skeletal muscle isoform } \\
\text { type } 2 \text { (MLRS) }\end{array}$ & -47.94 \\
\hline Somatotropin (SOMA) & 1332.49 & Collagen alpha-1(II) chain (CO2A1) & -34.45 \\
\hline Thyrotropin subunit beta (TSHB) & 27.90 & Transposon Ty3-I Gag-Pol polyprotein (YI31B) & -30.32 \\
\hline Probable cysteine-tRNA ligase, mitochondrial (SYCM) & 25.81 & Fructose-bisphosphate aldolase A (ALDOA) & -19.98 \\
\hline Gonadotropin alpha chain (GLHA) & 19.53 & Troponin T, fast skeletal muscle isoforms (TNNT3) & -18.43 \\
\hline Pentraxin-4 (PTX4) & 13.24 & Sodium channel protein type 4 subunit alpha B (SC4AB) & -14.00 \\
\hline Pro-opiomelanocortin (POMC) & 13.23 & $\begin{array}{l}\text { Sarcoplasmic/endoplasmic reticulum calcium ATPase } 1 \\
\text { (AT2A1) }\end{array}$ & -13.68 \\
\hline LINE-1 retrotransposable element ORF2 protein (LORF2) & 10.99 & Creatine kinase M-type (KCRM) & -12.46 \\
\hline Serine protease 48 (PRS48) & 9.97 & Actin, alpha skeletal muscle 2 (ACT2) & -11.73 \\
\hline Probable E3 ubiquitin-protein ligase HERC4 (HERC4) & 8.55 & Keratin, type I cytoskeletal 17 (K1C17) & -11.31 \\
\hline Sacsin (SACS) & 7.07 & Parvalbumin alpha (PRVA) & -10.45 \\
\hline C-X-C motif chemokine 9 (CXCL9) & 7.07 & Collagen alpha-1(II) chain (CO2A1) & -9.10 \\
\hline $\begin{array}{l}\text { Radical S-adenosyl methionine domain-containing protein } \\
2 \text { (RSAD2) }\end{array}$ & 6.63 & Keratin, type I cytoskeletal 13 (K1C13) & -8.06 \\
\hline Sacsin (SACS) & 6.37 & DNA damage-inducible transcript 4-like protein (DDT4L) & -5.60 \\
\hline Receptor-transporting protein 3 (RTP3) & 5.81 & Receptor-type tyrosine-protein phosphatase F (PTPRF) & -5.58 \\
\hline Receptor-type tyrosine-protein phosphatase F (PTPRF) & 5.75 & Metabotropic glutamate receptor 8 (GRM8) & -5.54 \\
\hline
\end{tabular}


Table 3 (continued)

\begin{tabular}{|c|c|c|c|}
\hline \multicolumn{2}{|l|}{ Up } & \multicolumn{2}{|l|}{ Down } \\
\hline Blast2GO UniProt/SwissProt description & FC & Blast2GO UniProt/SwissProt description & FC \\
\hline Complement C3 (CO3) & 5.66 & Alpha-1B adrenergic receptor (ADA1B) & -5.46 \\
\hline Protein quaking-A (QKIA) & 5.57 & Sodium channel protein type 4 subunit alpha B (SC4AB) & -5.30 \\
\hline Inter-alpha-trypsin inhibitor heavy chain $\mathrm{H} 2(\mathrm{ITIH} 2)$ & 5.03 & Amiloride-sensitive amine oxidase (AOC1) & -5.15 \\
\hline LINE-1 retrotransposable element ORF2 protein (LORF2) & 5.02 & DNA damage-inducible transcript 4-like protein (DDT4L) & -5.03 \\
\hline Dynein heavy chain 8, axonemal (DYH8) & 4.99 & $\begin{array}{l}\text { Bifunctional heparan sulfate N-deacetylase/N-sulfotrans- } \\
\text { ferase } 3 \text { (NDST3) }\end{array}$ & -5.02 \\
\hline $\begin{array}{l}\text { Retrovirus-related Pol polyprotein from transposon } 412 \\
\text { (POL4) }\end{array}$ & 4.73 & Leukocyte cell-derived chemotaxin-2 (LECT2) & -4.89 \\
\hline Inter-alpha-trypsin inhibitor heavy chain H5 (ITIH5) & 4.50 & Leukocyte cell-derived chemotaxin 1 (CNMD) & -4.89 \\
\hline WD repeat-containing protein on Y chromosome (WDY) & 4.43 & $\begin{array}{l}\text { Feline leukemia virus subgroup C receptor-related protein } \\
2 \text { (FLVC2) }\end{array}$ & -4.83 \\
\hline Filamin-C (FLNC) & 4.37 & Sulfotransferase family cytosolic 2B member 1 (ST2B1) & -4.79 \\
\hline
\end{tabular}

B

A

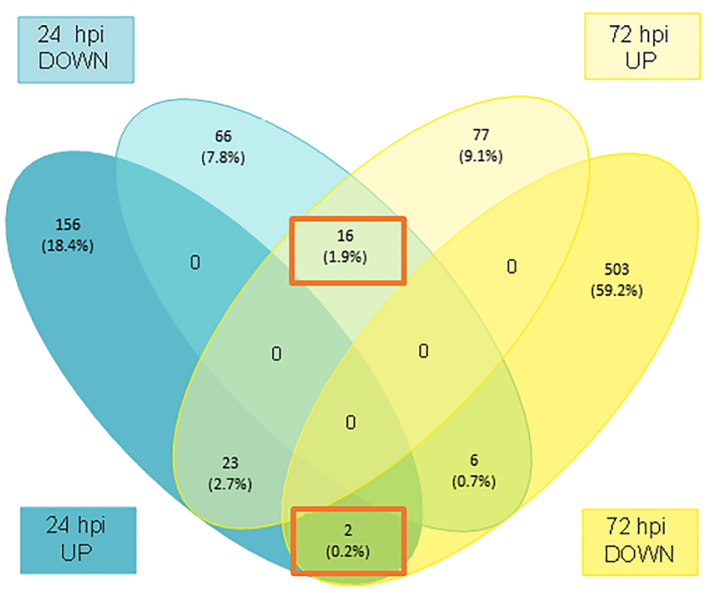

\section{Prolactin (PRL)}

Somatotropin (SOMA) - Growth hormone (GH)

Pro-opiomelanocortin (POMC)

Thyrotropin subunit beta (TSHB)

Gonadotropin alpha chain (GLHA)

Regulator of rDNA transcription protein 15 (RRT15)

LINE-1 retrotransposable element ORF2 protein (LORF2)

Serine protease 48 (PRS48)

Protein quaking-A (QKIA)

Synembryn-A (RIC8A)

LINE-1 retrotransposable element ORF2 protein (LORF2)

WD repeat-containing protein on $Y$ chromosome (WDY)

Receptor-type tyrosine-protein phosphatase F (PTPRF)

LINE-1 retrotransposable element ORF2 protein (LORF2)

Transmembrane protease serine 11F (TM11F)

Transposable element Tcb1 transposase (TCB1)

\section{C}

Leukocyte cell-derived chemotaxin-2 (LECT2) Glutamate receptor ionotropic, NMDA 2B (NMDE2)

$\begin{array}{rr}\text { FC 24 hpi } & \text { FC 72 hpi } \\ -101144.45 & 4713.60 \\ -2711.84 & 1332.49 \\ -349.84 & 13.23 \\ -172.68 & 27.90 \\ -71.08 & 19.53 \\ -7.20 & 2.32 \\ -3.75 & 2.76 \\ -3.61 & 9.97 \\ -3.51 & 5.57 \\ -3.19 & 3.24 \\ -2.97 & 5.02 \\ -2.96 & 4.43 \\ -2.92 & 5.75 \\ -2.70 & 10.99 \\ -2.52 & 4.03 \\ -2.34 & 2.57 \\ & \end{array}$

\begin{tabular}{cr} 
FC 24 hpi & \multicolumn{2}{l}{ FC 72 hpi } \\
3.55 & -4.89 \\
2.65 & -3.36 \\
\hline
\end{tabular}

Figure 4 Venn diagram of the up- and downregulated DEGs identified in the brain at $\mathbf{2 4}$ and $\mathbf{7 2}$ hpi. Some contigs showed a reversal of their modulation from upregulated to downregulated, or vice versa, between 24 and $72 \mathrm{hpi}$. nmde2 gene, encoding the neurotransmitter receptor Nmde2 (Figure 4C).

Neurotransmitters and their receptors are also involved in the activation and/or deactivation of the HPI axis. Indeed, we observed that a large number and various types of neurotransmitter receptors were modulated during infection with NNV (Table 4). In general, although with some exceptions, we observed overexpression of some neurotransmitter receptors at 24 hpi but downregulation at $72 \mathrm{hpi}$ (Table 4). Those neurotransmitter receptors that were overexpressed at $24 \mathrm{hpi}$ corresponded to serotonin and glutamate receptors, whereas at $72 \mathrm{~h}$, serotonin and glutamate receptors were mainly inhibited, as were acetylcholine and adrenergic receptors. Although some GABA receptors were slightly inhibited after $72 \mathrm{~h}$, gbrb1 was overexpressed $(\mathrm{FC}=4.26)$, and it was the most differentially modulated GABA receptor. Among all the modulated receptors, the highest fold change was observed for the serotonin receptor 5-hydroxytryptamine receptor $3 E(5 h t 3 e)$ at $24 \mathrm{hpi}$, which was overexpressed in infected animals by 52 -fold compared to control fish.

Among the enriched GO terms associated with the brain during NNV infection, we also found high representation of terms related to calcium homeostasis (Figures 3A, B). Excessive stimulation by neurotransmitters can cause excitotoxicity by increasing the massive influx 
Table 4 Genes encoding neurotransmitter receptors significantly modulated in the brain after NNV infection.

\begin{tabular}{|c|c|c|c|}
\hline $\begin{array}{l}\text { Type of neurotransmitter } \\
\text { receptor }\end{array}$ & Receptor or related protein & $24 \mathrm{hpi}$ & $72 \mathrm{hpi}$ \\
\hline \multirow[t]{3}{*}{ Serotonin receptors } & 5-hydroxytryptamine receptor $3 \mathrm{E}$ (5HT3E) & 51.82 & \\
\hline & 5-hydroxytryptamine receptor 5A (5HT5A) & & -3.19 \\
\hline & 5-hydroxytryptamine receptor $1 \mathrm{~F}$ (5HT1F) & & -2.74 \\
\hline \multirow[t]{20}{*}{ Glutamate receptors } & N-methyl-D-aspartate (NMDA) NMDA 1 & & -2.35 \\
\hline & N-methyl-D-aspartate (NMDA) NMDA 2A & & -2.77 \\
\hline & N-methyl-D-aspartate (NMDA) NMDA 2B & 2.65 & -3.36 \\
\hline & N-methyl-D-aspartate (NMDA) NMDA $2 \mathrm{C}$ & & 2.22 \\
\hline & N-methyl-D-aspartate (NMDA) NMDA 2D & & -2.38 \\
\hline & a-amino-3-hydroxy-5-methyl-4-isoazolepropionic acid (AMPA) AMPA1 (GluR-1) & & -2.32 \\
\hline & a-amino-3-hydroxy-5-methyl-4-isoazolepropionic acid (AMPA) AMPA2 (GluR-2) & 2.05 & \\
\hline & a-amino-3-hydroxy-5-methyl-4-isoazolepropionic acid (AMPA) AMPA3 (GluR-3) & & -2.68 \\
\hline & a-amino-3-hydroxy-5-methyl-4-isoazolepropionic acid (AMPA) AMPA4 (GluR-4) & & $-2,06$ \\
\hline & 2-carboxy-3-carboxymethyl-4-isopropenylpyrrolidine (kainate) 5 (GluK5) & & $-2,04$ \\
\hline & Metabotropic glutamate receptor 1 (mGluR1) & 2.12 & \\
\hline & Metabotropic glutamate receptor 4 (mGluR4) & & $-2,14$ \\
\hline & Metabotropic glutamate receptor 5 (mGluR5) & & -3.28 \\
\hline & Metabotropic glutamate receptor 8 (mGluR8) & & -5.54 \\
\hline & Vesicular glutamate transporter 1 (VGluT1) & 2.03 & \\
\hline & Vesicular glutamate transporter 2.1 (VGL2A) & & -2.24 \\
\hline & AMPA receptor-interacting protein GRIP1 & & 2.10 \\
\hline & Glutamate receptor-interacting protein 2 (GRIP2) & 2.01 & $2.01 \&-2.05$ \\
\hline & Kainate-binding protein. Glutamate receptor U1 (GLRK) & 2.06 & \\
\hline & Sodium-dependent glutamate/aspartate transporter 1 (EAA1, GLAST-1) & 2.51 & -2.39 \\
\hline \multirow[t]{6}{*}{ GABA receptors } & GABA(A) receptor subunit alpha-2 (GBRA2) & & -2.85 \\
\hline & GABA(A) receptor subunit alpha-5 (GBRA5) & & -2.63 \\
\hline & GABA(A) receptor subunit beta-1 (GBRB1) & & 4.26 \\
\hline & GABA(A) receptor subunit beta-3 (GBRB3) & & -3.07 \\
\hline & GABA(A) receptor subunit beta-4 (GBRB4) & & -2.41 \\
\hline & GABA(A) receptor subunit pi (GBRP) & & -2.43 \\
\hline \multirow[t]{4}{*}{ Acetylcholine receptors } & Muscarinic acetylcholine receptor M2 (ACM2) & & -2.14 \\
\hline & Neuronal acetylcholine receptor subunit alpha-3 (ACHA3) & & -3.14 \\
\hline & Neuronal acetylcholine receptor subunit alpha-3 (ACHA3) & & -2.70 \\
\hline & Neuronal acetylcholine receptor subunit alpha-7 (ACHA7) & & -3.24 \\
\hline \multirow[t]{3}{*}{ Adrenergic receptors } & Alpha-1B adrenergic receptor (ADA1B) & & -5.46 \\
\hline & Alpha-2B adrenergic receptor (ADA2B) & & -2.01 \\
\hline & Alpha-2Db adrenergic receptor (AA2DB) & & -2.70 \\
\hline
\end{tabular}

of calcium ions into cells [29]. Therefore, a similar pattern to that observed for the neurotransmitters could be expected for the genes encoding calcium transporters. When the DEGs included among the enriched biological processes related to calcium were represented in a heat map, we generally observed the overexpression of the calcium-related genes at 24 hpi (Figure 5A), but most of these genes were downregulated at $72 \mathrm{hpi}$ (Figure 5B). Based on the KEGG pathway analysis of calcium signalling, we identified the main cellular calcium regulators affected by infection with NNV at both sampling points (Figures 5C, D). As expected based on previous observations, at 24 hpi the changes in gene expression seemed to favour higher levels of calcium in the cytoplasm (overexpression of several calcium import channels), whereas at $72 \mathrm{hpi}$, the opposite response was observed (downregulation of calcium importers).

Therefore, NNV infection induced strong modulation of genes related to the HPI axis in the brain by affecting the expression of the genes encoding neurotransmitter 


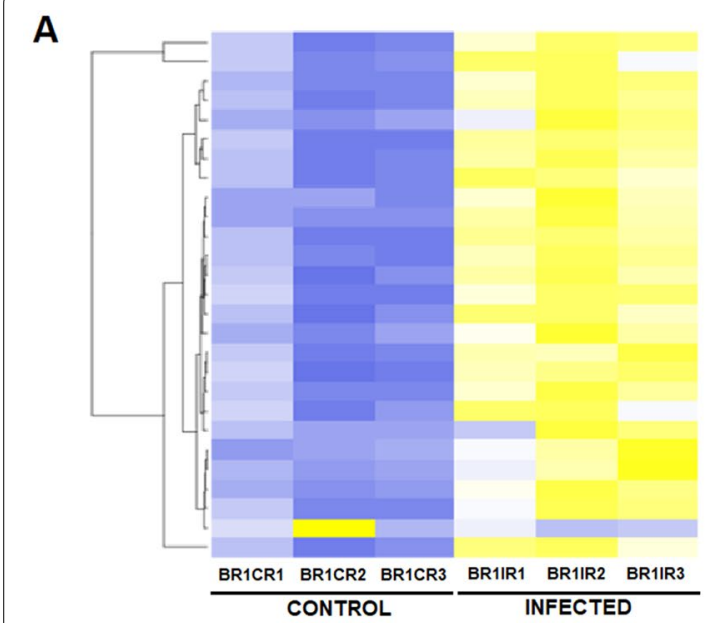

C

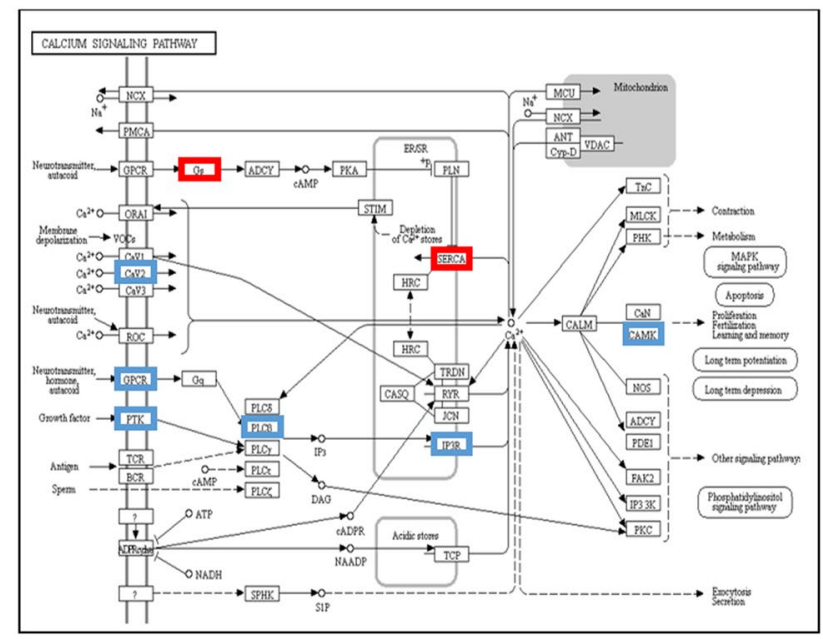

B

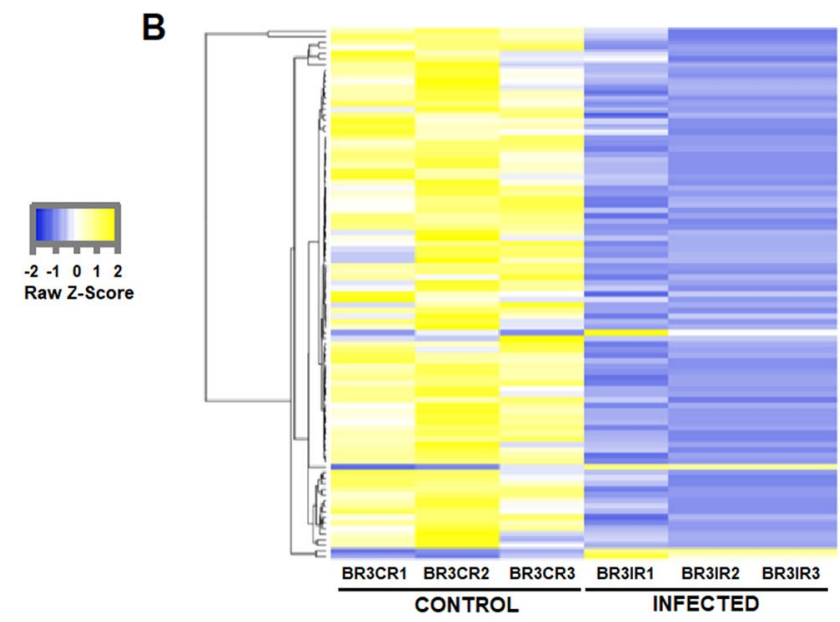

D

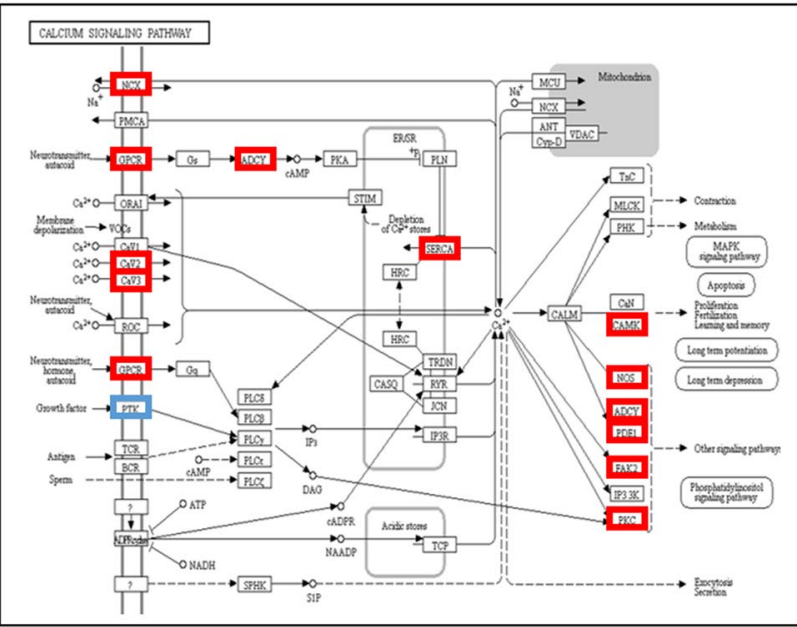

Figure 5 Modulation of DEGs related to calcium transport and homeostasis in the brain at $\mathbf{2 4}$ and $\mathbf{7 2}$ hpi. Heat maps representing the $\log _{2}$-transformed TPM expression values of the calcium-related contigs at $24 \mathbf{A}$ and $72 \mathrm{hpi} \mathbf{B}$. Colours represent transcript expression ranging from blue (less expressed) to yellow (more expressed). Representation of the modulation of the calcium signalling KEGG pathway components according to the RNA-Seq results at $24 \mathbf{C}$ and $72 \mathrm{hpi} \mathbf{D}$.

receptors, calcium transporters and pituitary hormones. However, the tendencies were mainly opposite between the two sampling points.

\section{HPI axis modulation in the head kidney}

Adrenocorticotropic hormone (ACTH) stimulates the production of cortisol, the main stress hormone, by the interrenal cells of the head kidney. When we analysed the effect of NNV in head kidney samples, we found that there were only 17 annotated DEGs at $24 \mathrm{hpi}$, and most of the upregulated genes encoded enzymes involved in the final steps of the steroid hormone biosynthesis pathway, specifically related to the transformation of cholesterol into cortisol (Table 5; Additional file 5): cytochrome p450 11b, mitochondrial (cyp11b1), steroidogenic acute regulatory protein, mitochondrial (star), steroid 21-hydroxylase (cyp21a), cytochrome p450 17a1 (cyp17a1), 3 beta-hydroxysteroid dehydrogenase (3bhsd) and cholesterol side-chain cleavage enzyme, mitochondrial (cyp11a1). None of these genes were significantly modulated after $72 \mathrm{~h}$.

\section{Effect of cortisol on defence against NNV}

The modest modulation of immune genes contrasted with the broad, intense changes in the expression of the genes involved in the HPI axis. The individuals carrying the cortisol implant showed a lower survival rate (5.3\%) compared to those inoculated with the vehicle alone (62.9\%) (Figure 6A), which was associated with a higher NNV level detected by qPCR at 72 hpi (Figure 6B). 
Table 5 Top 25 up- and downregulated DEGs in the head kidney at 24 and $72 \mathrm{hpi}$.

\begin{tabular}{|c|c|c|c|}
\hline \multicolumn{2}{|l|}{ Up } & \multicolumn{2}{|l|}{ Down } \\
\hline Blast2GO UniProt/SwissProt description & FC & Blast2GO UniProt/SwissProt description & FC \\
\hline \multicolumn{4}{|l|}{24 hpi } \\
\hline Cytochrome P450 11B, mitochondrial (CP11B) & 7007.72 & Transcription cofactor vestigial-like protein 4 (VGLL4) & -88.03 \\
\hline Steroidogenic acute regulatory protein, mitochondrial (STAR) & 1423.20 & Keratin, type I cytoskeletal 13 (K1C13) & -71.73 \\
\hline Cytochrome P450 11B, mitochondrial (CP11B) & 453.32 & NLR family CARD domain-containing protein 3 (NLRC3) & -64.71 \\
\hline Steroid 21-hydroxylase (CP21A) & 349.77 & Keratin, type II cytoskeletal 8 (K2C8) & -60.16 \\
\hline Steroid 21-hydroxylase (CP21A) & 326.02 & $\begin{array}{l}\text { Translocase of chloroplast } 34 \text { homolog, chloroplastic } \\
\text { (TOC34) }\end{array}$ & -15.80 \\
\hline Steroid 17-alpha-hydroxylase/17,20 lyase (CP17A) & 307.93 & Carbonic anhydrase 1 (CAH1) & -5.18 \\
\hline Steroid 17-alpha-hydroxylase/17,20 lyase (CP17A) & 95.58 & & \\
\hline $\begin{array}{l}3 \text { beta-hydroxysteroid dehydrogenase/Delta 5-> 4-isomerase } \\
\text { type } 1 \text { (3BHSD) }\end{array}$ & 61.79 & & \\
\hline Nuclear receptor subfamily 5 group A member 2 (NR5A2) & 43.00 & & \\
\hline Chemokine-like receptor 1 (CML1) & 17.97 & & \\
\hline Cholesterol side-chain cleavage enzyme, mitochondrial (CP11A) & 4.37 & & \\
\hline \multicolumn{4}{|l|}{72 hpi } \\
\hline Acidic mammalian chitinase (CHIA) & 32.07 & Contactin-associated protein-like 5 (CNTP5) & -39.47 \\
\hline Transposon Ty3-I Gag-Pol polyprotein (Y|31B) & 10.35 & Elongation factor 1-gamma (EF1G) & -32.60 \\
\hline Myosin-binding protein C, fast-type (MYPC2) & 6.51 & Phosphoserine aminotransferase (PSAT) & -6.24 \\
\hline Fructose-bisphosphate aldolase A (ALDOA) & 5.12 & Lanosterol 14-alpha demethylase (CP51A) & -6.08 \\
\hline Neuronal acetylcholine receptor subunit beta-4 (ACHB4) & 2.84 & D-3-phosphoglycerate dehydrogenase (3-PGDH) & -5.03 \\
\hline Glyceraldehyde-3-phosphate dehydrogenase (G3P) & 2.75 & Calreticulin (CALR) & -4.42 \\
\hline \multirow[t]{19}{*}{ Rieske domain-containing protein (RFESD) } & 2.08 & Protein FAM111A (F111A) & -4.16 \\
\hline & & Calreticulin (CALR) & -3.74 \\
\hline & & Mitochondrial glutamate carrier 1 (GHC1) & -3.43 \\
\hline & & Arachidonate 12-lipoxygenase, 12R-type (LX12B) & -3.20 \\
\hline & & Ubiquitin carboxyl-terminal hydrolase isozyme L3 (UCHL3) & -3.06 \\
\hline & & Fibronectin (FINC) & -3.05 \\
\hline & & Argininosuccinate synthase (ASSY) & -3.04 \\
\hline & & Quinone oxidoreductase PIG3 (QORX) & -2.88 \\
\hline & & Calreticulin (CALR) & -2.76 \\
\hline & & Stromal cell-derived factor 2-like protein 1 (SDF2L) & -2.75 \\
\hline & & Endoplasmic reticulum chaperone BiP (BIP) & -2.71 \\
\hline & & Inositol-3-phosphate synthase 1-A (INO1A) & -2.69 \\
\hline & & Protein disulfide-isomerase A6 (PDIA6) & -2.63 \\
\hline & & Spermidine synthase (SPEE) & -2.62 \\
\hline & & Nuclear mitotic apparatus protein 1 (NUMA1) & -2.49 \\
\hline & & Protein disulfide-isomerase A4 (PDIA4) & -2.47 \\
\hline & & Rac GTPase-activating protein 1 (RGAP1) & -2.45 \\
\hline & & L-lactate dehydrogenase A chain (LDHA) & -2.40 \\
\hline & & Histone chaperone asf1b-B (AS1BB) & -2.36 \\
\hline
\end{tabular}

Interestingly, cortisol did not significantly affect the expression of the ighm gene in the absence or presence of NNV infection (Figure 6C). Surprisingly, when the IgM protein content was analysed, higher levels of IgM were detected at 72 hpi in the animals infected with NNV and carrying cortisol implants compared to those infected but injected with the vehicle (Figure 6D).
Therefore, although our results showed an increase in sea bass susceptibility to NNV with cortisol overload, it seems that this lower resistance was not mediated by IgM synthesis suppression. We also observed higher expression of $\mathrm{prl}$ associated with the combination of cortisol overload and NNV infection after 72 hpi compared to those animals inoculated with the vehicle and 


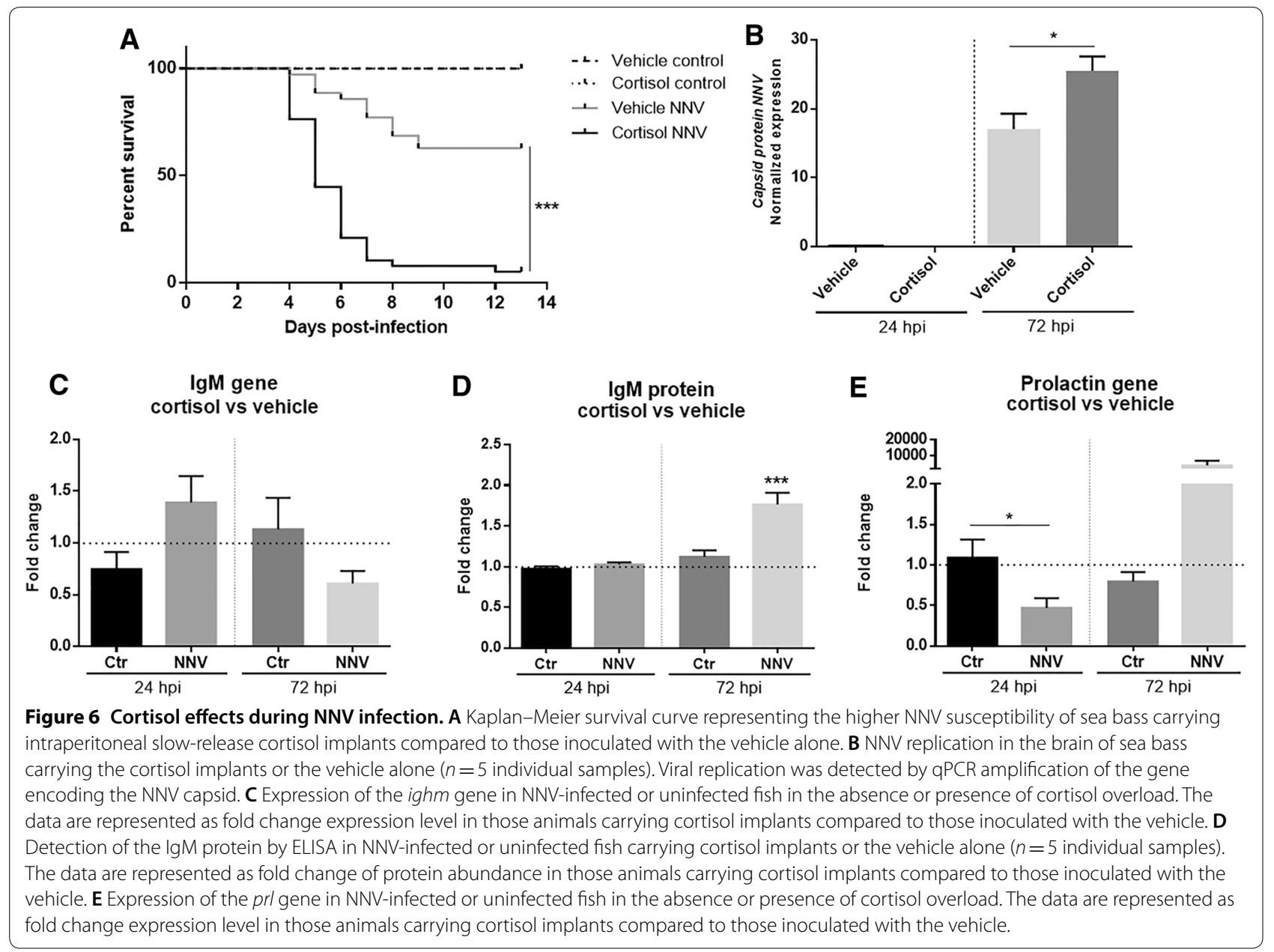

infected with NNV, although due to the high deviation among the samples, differences were not statistically significant (Figure 6E).

\section{ROS production modulation during nodavirus infection}

Cortisol synthesis involves the production of ROS due to the activity of the steroidogenic cytochrome P450 enzymes (Quinn and Payne, 1984, 1985; Hornsby, 1987). However, at $72 \mathrm{hpi}$, we observed the downregulation of some genes encoding enzymes implicated in ROS production in the head kidney, including erol-like protein alpha (ero1a), hypoxia up-regulated protein 1 (hyou1), protein disulfide-isomerase a4 (pdia4) and quinone oxidoreductase pig3 (qorx). Therefore, we can assume that there was a shift in ROS generation in the head kidney from 24 to $72 \mathrm{hpi}$. To better understand the effect of NNV on the production of ROS, we conducted the in vitro infection of head kidney cells and measured ROS production at different times post-infection. The results showed that at $1 \mathrm{hpi}$, there was a significantly higher ROS level in the infected cells (Figure 7A). However, after
$24 \mathrm{~h}, \mathrm{ROS}$ production decreased in the infected cells, and this pattern was maintained at 48 and 72 hpi (Figure 7A). These data could be explained by the downregulation of ero1 in the late stages of infection, as the product of this gene is the largest producer of $\mathrm{H}_{2} \mathrm{O}_{2}$ in the ER [30]. When we analysed the modulation of ROS production in vivo at 1 and $5 \mathrm{dpi}$, we found that ROS production in head kidney cells decreased with the time of infection, showing significant inhibition at $5 \mathrm{dpi}$ compared to the uninfected fish (Figure 7B).

To investigate how the levels of ROS could affect the replication of NNV, we further evaluated the antiviral effects of these radicals by using $\mathrm{H}_{2} \mathrm{O}_{2}$. We found that when the virus was incubated with $\mathrm{H}_{2} \mathrm{O}_{2}$ for $5 \mathrm{~h}$, there was no appreciable effect on NNV replication in SNN-1 cells (Figure 7C). However, when the treatment was maintained for $24 \mathrm{~h}$, viral replication was significantly reduced compared to that of the non-treated virus (Figure 7C). 
A

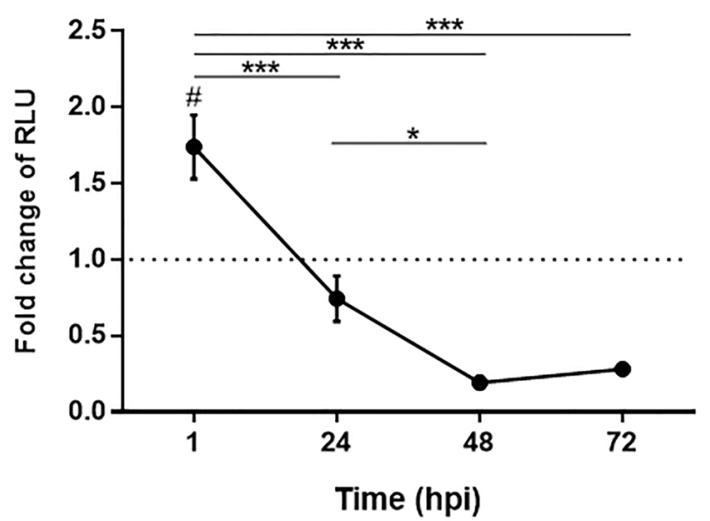

B

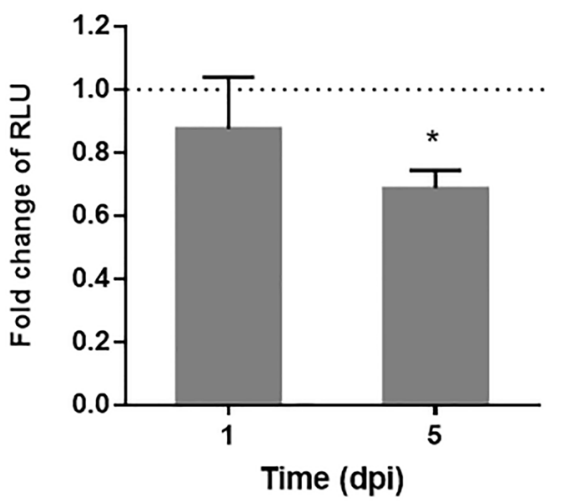

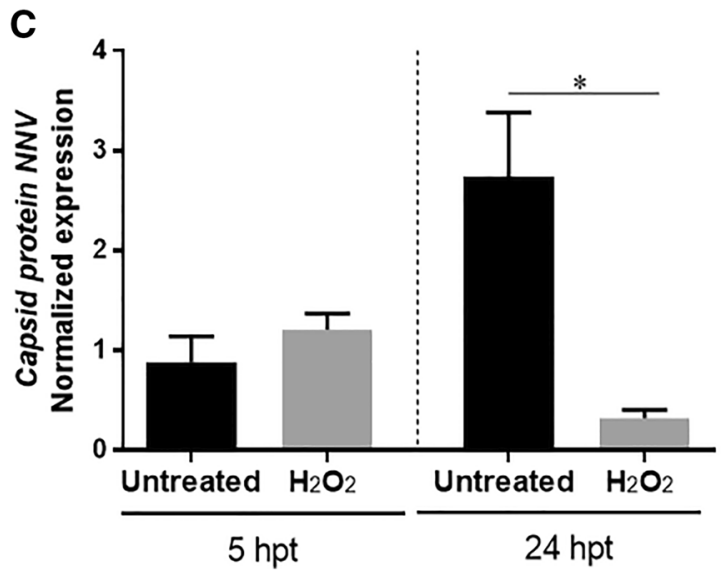

Figure 7 Effect of NNV on cellular ROS production and the antiviral activity of oxygen radicals. A ROS production by head kidney leukocytes during in vitro infection with NNV. The data are represented as the fold change relative luminescence units (RLUs) in the infected samples compared to those of the uninfected cells at each sampling point. Statistically significant differences between NNV-infected and control cells were represented with \#, whereas differences along time for the infected cells were represented with *. B ROS detection in head kidney leukocytes at 1 and 5 dpi after in vivo infection with NNV. The data are represented as the fold change of the RLUs in the infected fish compared to those measured for the uninfected animals. C Replication levels of NNV after treatment with $\mathrm{H}_{2} \mathrm{O}_{2}$ measured by qPCR amplification of the gene encoding the NNV capsid. hpt: hours post-treatment.

\section{Calcium modifications interfere with ROS production and nodavirus replication}

We analysed the calcium load within SSN-1 cells during nodavirus infection by using the fluorescent probe FLUO-4 AM, which is used to measure calcium $\left(\mathrm{Ca}^{2+}\right)$ concentrations inside living cells. As shown in Figure 8A, $\mathrm{NNV}$-infected cells showed a lower $\mathrm{Ca}^{2+}$ concentration than uninfected cells at all tested times post-infection (24, 72 and $96 \mathrm{hpi})$. To further confirm the effect of the modulation of the genes encoding calcium transporters in the brain after NNV challenge, we also infected European sea bass in vivo; at 1 and $5 \mathrm{dpi}$, the brain was sampled, and the tissue was disintegrated to measure the $\mathrm{Ca}^{2+}$ concentration. As observed for the SNN-1 cells, the intracellular calcium concentration decreased with the time of infection (Figure 8B).

We further evaluated how these changes in the cellular calcium content in the infected cells could affect ROS production and NNV replication. For this purpose, we treated a primary culture of head kidney cells with BAPTA-AM or EGTA. We observed a significant decrease in ROS production when cells were treated with BAPTA-AM but not with EGTA, indicating that the sequestration of intracellular free calcium influences the production of ROS by cells (Figure 8C).

If infected cells show alterations in their calcium load and in the expression of different calcium channels (which in turn affect the production of ROS), the 

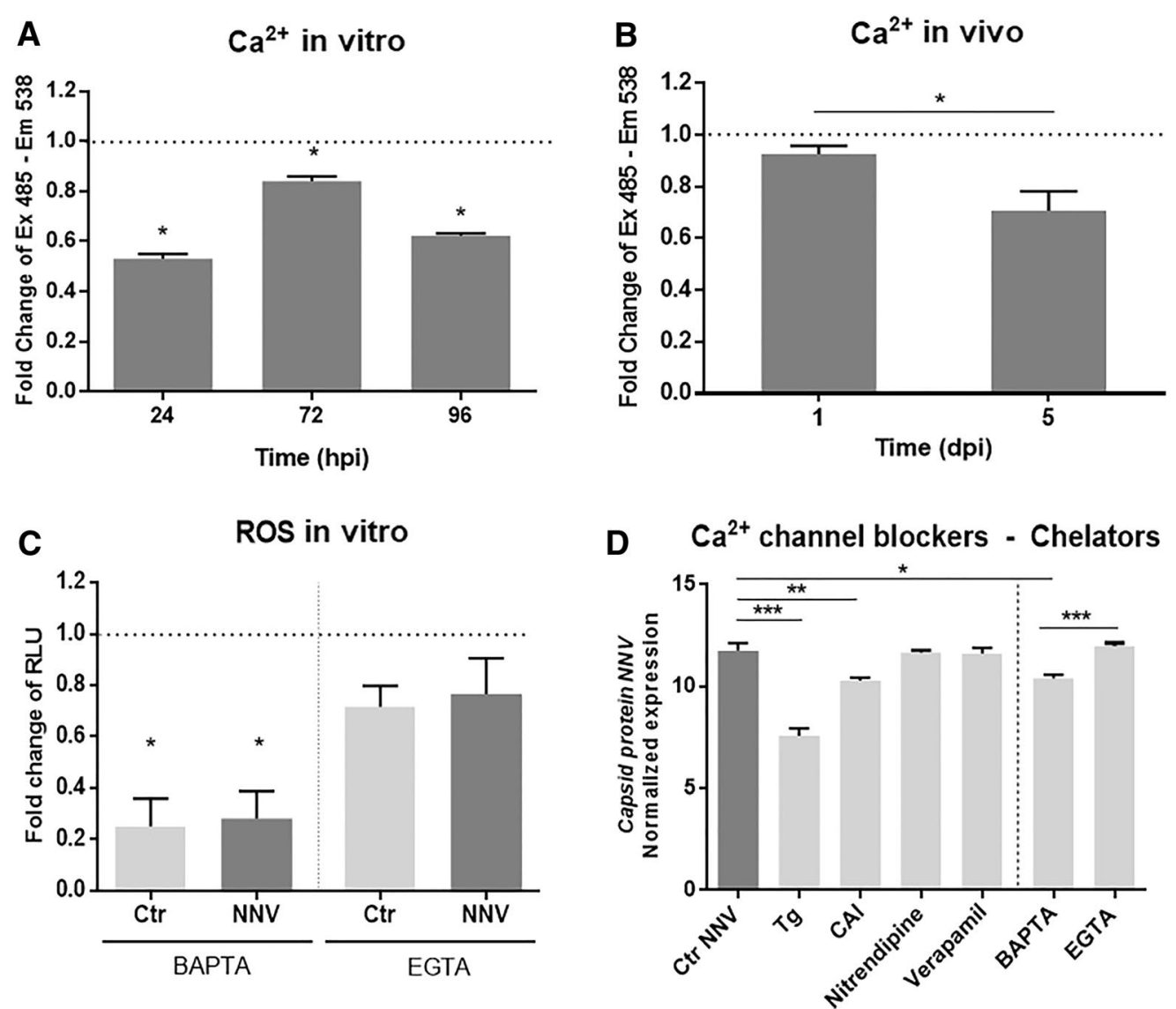

Figure 8 Modulation of the intracellular calcium content by NNV infection and the effect of cytoplasmic calcium availability on ROS production and NNV replication. A Intracellular calcium measurement with the fluorescent probe FLUO-4 AM in SSN-1 cells during infection with NNV. Values are the fold change of the fluorescence value obtained for the infected cells compared to the uninfected ones. B Calcium content measurement with FLUO-4 AM in brain cells isolated from in vivo NNV-infected sea bass and represented as the fold change value compared to the uninfected fish. C ROS production detection in head kidney leukocytes after in vitro pretreatment with the calcium chelators BAPTA-AM and EGTA and with or without NNV infection for $1 \mathrm{~h}$. The data are represented as the fold change compared to untreated and uninfected cells. D Replication of NNV in SSN-1 cells after pretreatment with calcium channel blockers and chelators and infection with NNV for $48 \mathrm{~h}$. Viral replication was detected by qPCR amplification of the gene encoding the NNV capsid.

modulation of calcium could influence the replication of the virus. To better understand this effect, we tested different calcium channel blockers and calcium chelators. When SNN-1 cells were pretreated for $2 \mathrm{~h}$ with the channel blocker CAI, thapsigargin and the intracellular calcium chelator BAPTA-AM and then infected for $48 \mathrm{~h}$, a significant reduction in the replication of $\mathrm{NNV}$ was observed compared to the untreated but infected cells (Figure 8D). These results demonstrate that although $\mathrm{Ca}^{2+}$ overload could negatively impact NNV replication, the virus requires $\mathrm{Ca}^{2+}$ availability.

\section{Validation of the RNA-Seq results}

For the validation of the RNA-Seq results, some of the most differentially regulated genes in each tissue were selected and analysed by qPCR. For the validation of the brain data, the $b 2$ bradykinin receptor (bdkrb2), leukocyte cell-derived chemotaxin-2 (lect2), prolactin (prl), fructose-bisphosphate aldolase a (aldoa), sacsin (sacs) and DNA damage-inducible transcript 4-like protein (ddit4l) genes were chosen. For validation of the head kidney results, the cholesterol side-chain cleavage enzyme mitochondrial (cyp11a1), cytochrome p450 11B mitochondrial (cyp11b1), steroid 17-alphahydroxylase/17,20 lyase (cyp17a1), steroid 21-hydroxylase (cyp21a), steroidogenic acute regulatory protein mitochondrial (star) and calreticulin (calr) genes were chosen (Additional file 6). The Pearson's correlation coefficient between the RNA-Seq and qPCR data was $r=0.903$. Additionally, the expression of three genes significantly modulated in brain at 24 and $72 \mathrm{hpi}$ (lect2, prl and aldoa) was analysed 
in an independent experiment composed by 5 individual biological replicates. For this experiment, the Pearson's correlation coefficient between the RNA-Seq and qPCR data was $r=0.835$ (Additional file 6).

\section{Discussion}

Nervous necrosis virus (NNV) exhibits a neurotropic nature and causes damage to the nervous system (brain, retina and spinal cord) of infected fish [2]. For this reason, understanding how the brain responds to its first contact with the virus is critical for elucidating the antiviral strategies of this immune-privileged organ. The immune-privileged tissue concept suggests the existence of different conditions that help to control the access of pathogens to the central nervous system (CNS) but also the exacerbation of inflammation [31]. This is why both pro-inflammatory and anti-inflammatory cytokines are overexpressed after stimulation by several types of stressors, including pathogens and vaccines [32]. These responses are thought to be an evolutionary adaptation to protect indispensable organs with limited regeneration capacities from uncontrolled inflammation [33]. However, some pathogens, such as NNV, can overcome these physiological and immunological barriers and reach the CNS, but circulating immune cells can also migrate to the CNS and, together with resident immune cells, generate a response against the pathogen. A powerful immune response in the brain could lead to severe damage as a consequence of the activated pro-inflammatory mechanisms, whereas the absence of response could allow the persistence and spreading of the pathogen. This situation generates interesting an interplay between "fighting" and "tolerance".

Here, we sought to study the response of D. labrax to infection by NNV, one of the most threatening pathogens in the culture of this important commercial fish species. Some previous studies have revealed the overexpression of certain immune genes after in vivo or in vitro infection with NNV in both European sea bass [14-22] and other fish species [5, 6, 8, 10-13, 20,34], but the present study is the first to conduct RNA-Seq in D. labrax after in vivo infection with NNV.

Among the most differentially modulated genes in the brain, we observed high representation of pituitary hormones involved in the hypothalamic-pituitary-interrenal (HPI) axis, which is equivalent to the hypothalamicpituitary-adrenal (HPA) axis of mammals. The HPI axis is activated under stress conditions and culminates in the secretion of cortisol by interrenal cells [35]. Cortisol is the main active corticosteroid in fish [36], and its secretion is induced by the release of adrenocorticotropic hormone $(\mathrm{ACTH})$ by the pituitary gland. The released $\mathrm{ACTH}$ activates the steroidogenic signalling pathway, leading to cortisol secretion as the final product of HPI axis activation [35].

Based on our transcriptome data, this stress response seemed to be activated at 24 hpi but attenuated after $72 \mathrm{~h}$ (Figure 9). At the earlier sampling point, we found overexpression of the serotonin and glutamate receptors in the brain, both of which are activators of the HPA axis by increasing corticotropin-releasing hormone $(\mathrm{CRH})$ signalling systems [37, 38]. However, we did not observe changes in crh gene expression after NNV infection, and even the genes encoding pituitary hormones were downregulated at this point, including pomc and, consequently, ACTH levels. The only genes that were differentially modulated in the head kidney were those encoding enzymes involved in the synthesis of cortisol from cholesterol, which is indicative of HPI axis activation (Figure 9). Indeed, the downregulation of pituitary hormones could be explained by the negative feedback established between cortisol release and the recurrent synthesis of hypothalamic and pituitary hormones [35]. Similar results were observed in the rainbow trout head kidney after treatment with Vibrio bacterin [32]. Moreover, our results are supported by a recent paper on the effects of vaccine exposure in seabream (Sparus aurata). Thus, the gene expression responsiveness of the brain and pituitary to biotic stressors is low compared to the response induced by a physical stressor such as air exposure, meaning that acute abiotic stressors generate a significant neuroendocrine reaction, whereas biotic stressor reactions are modulated in the brain and pituitary [39].

The effect of stressors in animals involves a significant allostatic load, i.e., a sudden requirement for energy and resources. This means that most of the immediately available resources are diverted to stress response mechanisms to cope with the stressor, particularly those related to the initial rapid fight and flight responses (cardiovascular, respiratory, tissue perfusion; see [40]), while more routine metabolic and growth processes are downregulated. Therefore, responses that require a significant amount of energy and take some time, such as some immune responses, are delayed or postponed. This could explain the lack of response of immune genes observed at early time points $(24 \mathrm{~h})$ in the present work, as found for the Ig genes. When a stressor lasts longer, regulatory and feedback mechanisms allow other responses to the situation, as occurred after $72 \mathrm{~h}$. This explains why genes related to growth and energetics, such as those encoding prolactin, somatolactin and somatotropin (Table 3), were severely downregulated at $24 \mathrm{~h}$ but upregulated at $72 \mathrm{~h}$.

Cortisol modulates the immune response by provoking immunosuppression [23, 41]. Consequently, we observed the nearly total absence of an immune response at $24 \mathrm{hpi}$, and some immune-related genes were even 


\section{Early antiviral respose}

(24 hpi)
Late antiviral respose

(72 hpi)

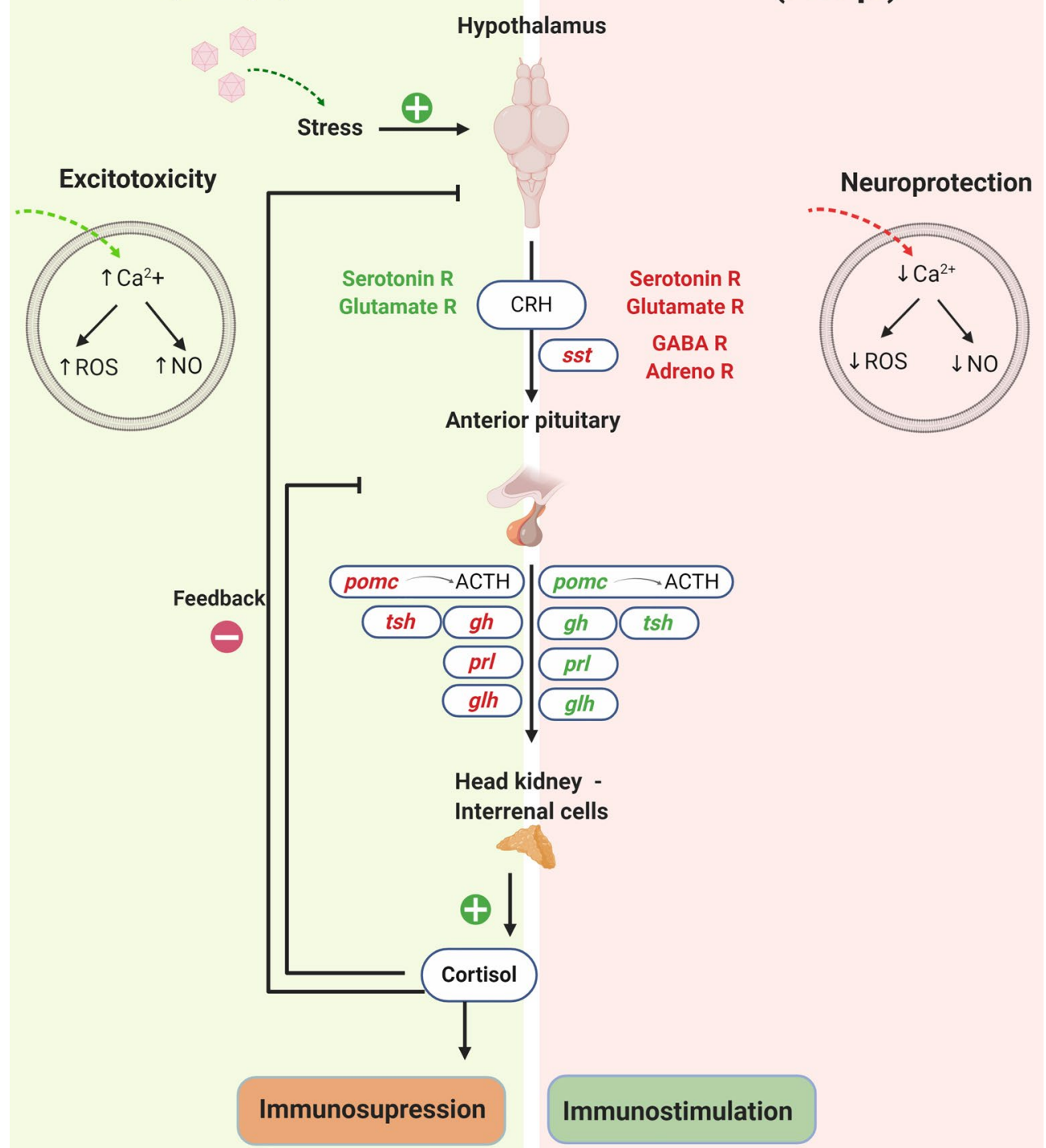

Figure 9 Schematic representation of the predicted alterations of the hypothalamic-pituitary-interrenal (HPI) axis after NNV infection and its associated effects based on the transcriptome data. Green indicates genes upregulated according to the RNA-Seq data; red indicates genes downregulated according to the RNA-Seq data.

downregulated at that time (including the gene encoding IgM), which could also be explained by high cortisol levels. In previous works based on qPCR analysis, overexpression of inflammation and antiviral immune genes was observed both in head kidney and brain from D. labrax infected with NNV [15, 17-19]. One of the most commonly analysed genes is the type I interferon-stimulated gene myxovirus resistance gene $(m x)$ [15, 17-19], suggesting the activation of the main antiviral pathway, the type I interferon response. The absence of this response in our RNA-Seq results could be directly conditioned by the high stress response reached in the animals, which at the same time could influence the survival. Pijanowski et al. observed that those common carp (Cyprinus carpio) lines more susceptible to bacterial and parasite infection also showed a higher ability to respond to stress, whereas the highly resistant lines showed modest modulation of stress-related factors, revealing a certain potential correlation between stress response and infectious disease susceptibility [42]. Based on this, the genetic background 
of the animals could be conditioning both the stress and immune response.

It has been previously suggested that the adaptive immune response is critical in the defence against NNV, even at early times post-infection [22, 43-45]. Considering this suggestion and the observed overexpression of the genes involved in cortisol synthesis in the head kidney, we further investigated whether cortisol overload increases the susceptibility of European sea bass to NNV. However, although the administration of cortisol implants in the peritoneum increased the susceptibility of European sea bass to NNV, they did not negatively affect the synthesis of IgM. Although, in general terms, stressful conditions or cortisol administration decreased the IgM levels in different teleost species, some exceptions were observed (see [46]). Based on our results and the conclusions by Parra et al. [46], it seems that the regulation of the immune system by the neuroendocrine machinery is more complex than the interaction of cortisol with its receptors, and other components could be involved in the control of the immune response. Indeed, in the present work we observed that at 72 hpi higher IgM levels were found in those animals infected with NNV and carrying the cortisol implants compared to those infected but inoculated with the vehicle, suggesting that the synergy of the two stimuli may have increased IgM synthesis. High prolactin levels have been previously related to IgM synthesis in rainbow trout (Oncorhynchus mykiss) [47], and we confirmed that $\mathrm{prl}$ gene expression was also elevated at $72 \mathrm{hpi}$ in the presence of the combination of the cortisol implant + NNV. How the combination of cortisol and NNV infection potentiates the expression of $\mathrm{prl}$ remains to be elucidated.

The hyperactivation of neurotransmitter receptors, especially glutamate receptors, generates excitotoxicity, which is defined as cell death resulting from the toxic effects of excitatory amino acids [29]. Prolonged exposure to glutamate generates an excessive influx of $\mathrm{Ca}^{2+}$ into neurons, which is highly neurotoxic and results in neuronal degeneration by increasing the production of nitric oxide (NO) and ROS, among other mechanisms [29]. Indeed, at $24 \mathrm{hpi}$, the expression of genes involved in calcium transport and cellular homeostasis seemed to be directed toward increasing $\mathrm{Ca}^{2+}$ levels into the cytoplasm, and some genes involved in ROS production, such as ecto-NOX disulfide-thiol exchanger 1 (enox1), were also overexpressed (Figure 9). As a consequence, the host response at this early point could favour neuronal damage as well as an immunosuppressive status. The high ROS production associated with increased intracellular calcium would be harmful to NNV, as shown in the present work. Indeed, whereas physiological levels of intracellular $\mathrm{Ca}^{2+}$ are necessary for efficient NNV replication, an excess of $\mathrm{Ca}^{2+}$ would be pernicious. Calcium ions are required for the efficient virion assembly and infectivity of betanodaviruses [48]. As we also observed in this work, the NNV was able to modulate the ROS production, and this seems to be highly dependent on $\mathrm{Ca}^{2+}$ availability. However, ROS production tended to decrease with time. The transcriptome response also completely changed at $72 \mathrm{hpi}$, most likely as a response to protect neurons from the damage caused by excitotoxicity or to overcome the immunosuppressive effect of cortisol (Figure 9). The overexpression of serotonin and glutamate receptors practically disappeared, and some of these receptors were even downregulated at this sampling point. Moreover, the immunoglobulin superfamily member 11 (igsf11) gene, encoding an adhesion molecule implicated in the synaptic stabilization of glutamate receptors [49], was inhibited, as was the glucocorticoid modulatory elementbinding protein 1 (gmeb1) gene, which produces a protein that increases sensitivity to glucocorticoids [50]. Interestingly, the most upregulated neurotransmitter receptor at 72 hpi was $G A B A(A)$ receptor subunit beta-1 (gbrb1), which inhibits HPA axis activation [50]. Accordingly, three adrenergic receptors that mainly play an excitatory role in the regulation of the HPA axis [51] were downregulated. As expected, the modulation of cellular calcium regulators completely changed after $72 \mathrm{~h}$, and most of the genes encoding $\mathrm{Ca}^{2+}$ importers were downregulated. Consequently, the genes encoding the enzymes involved in $\mathrm{NO}$ and ROS production were not induced, and even the nitric oxide synthase gene nos 1 was downregulated. It has been previously demonstrated that the inhibition of neuronal nitric oxide synthase protects against excitotoxicity [52].

The genes encoding the hypothalamic hormone somatostatin (sst) and somatostatin receptor type 2 (sstr2) were inhibited at $72 \mathrm{hpi}$, which probably led to the overexpression of the pituitary hormone repertoire (Figure 9), due to its inhibitory activity in the pituitary gland [53]. Among the pituitary hormones, prolactin plays a critical stimulatory role in the proliferation of immune cells and the synthesis of immune factors [54] but also acts as a neuroprotective factor by reducing the $\mathrm{Ca}^{2+}$ overload induced by an excess of glutamate [55]. As a consequence, the production of NO is inhibited by prolactin [56]. Additionally, the pomc gene is overexpressed at this time point, based on which we might expect an upregulation of the genes involved in the synthesis of cortisol, which were not found to be significantly affected. At the same time, cortisol establishes negative feedback towards pituitary hormones, including $\mathrm{ACTH}$, to control the magnitude of glucocorticoid release [35], which could explain the downregulation of pomc at 24 hpi but its higher expression 
after $72 \mathrm{~h}$. As a consequence of all these modulations, the antiviral response might be more active at this time point, but although some relevant immune genes were overexpressed after $72 \mathrm{hpi}$, the response was still very discrete. At later sampling points, the antiviral response would most likely be more pronounced. Indeed, in the experiment involving cortisol implants, NNV induced the expression of ighm at $72 \mathrm{hpi}$, but this probably depends on the intensity of infection.

Alterations in the HPA axis have been observed in association with neurotropic and non-neurotropic virus and bacterial infections in mammals and even in association with viral and bacterial components [57, 58]. However, this is the first time that the modulation of the HPI axis has been described under teleost neurotropic virus infection. Although some of the processes described in this work need to be studied in a more detailed way, it seems that the initial boundless stress response is counteracted by the host. This could be a strategy to reduce the neural damage associated with excitotoxicity and a mechanism for increasing the immune response. Nevertheless, a higher immune response would increase inflammation due to the activity of pro-inflammatory cytokines, which could be the reason for the high susceptibility of European sea bass to NNV: an equilibrium between the neuroprotective environment and efficient immune response is difficult to achieve. The study of this response in fish species resistant to NNV, such as gilthead seabream (Sparus aurata) [59], could help to better elucidate this complex interplay.

\section{Supplementary information}

Supplementary information accompanies this paper at https://doi. org/10.1186/s13567-020-00784-y.

\section{Additional file 1 . Sequence of the primer pairs used in this experiment.}

Additional file 2. Video showing the erratic swimming behaviours of juvenile European sea bass infected with NNV.

Additional file 3. Differential expression analysis in the brain at 24 and 72 hpi with NNV.

Additional file 4. Differential expression analysis in the head kidney at 24 and 72 hpi with NNV.

Additional file 5. Schematic representation of the contigs significantly differentially modulated in the head kidney at $24 \mathrm{hpi}$ with NNV. These DEGs mainly consisted of the genes encoding those enzymes involved in the last steps of cortisol synthesis.

Additional file 6 . Validation of the RNA-Seq results by qPCR. A Comparison of RNA-Seq and qPCR data for genes significantly modulated in brain. B) Comparison of RNA-Seq and GPCR data for genes significantly modulated in head kidney. C) Correlation between the RNA-Seq and GPCR data. D) Validation of three genes significantly modulated in brain at 24 and $72 \mathrm{hpi}$ in an independent experiment.
Abbreviations

BSA: Bovine serum albumin; DEGs: differentially expressed genes; DMSO: dimethyl sulfoxide; Dpi: days post-infection; ELISA: enzyme-linked immunosorbent assay; FBS: foetal bovine serum; FDR: false discovery rate; GO: Gene ontology; HPA: Hypothalamic-pituitary-adrenal; Hpi: hours post-infection; $\mathrm{HPI}$ : hypothalamic-pituitary-interrenal; i.m.: intramuscularly; i.p.: intraperinoteally; NNV: nervous necrosis virus; PBS: phosphate-buffered saline; PMA: phorbol myristate acetate; RGNNV: red-spotted grouper nervous necrosis virus; RNASeq: RNA sequencing; ROS: reactive oxygen species; RT: room temperature; TPM: transcripts per million; VER: viral encephalopathy and retinopathy.

\section{Acknowledgements}

We thank Judit Castro and the IIM-CSIC aquarium staff for their technical assistance. We also acknowledge support of the publication fee by the CSIC Open Access Publication Support Initiative through its Unit of Information Resources for Research (URICI).

\section{Authors' contributions}

$\mathrm{BN}$ and $\mathrm{AF}$ conceived and designed the experimental approach. RL and PP conducted all the laboratory experiments. RL, PP, AF, WV-M and CG-E performed the bioinformatic analyses and data curation. LT participated in the study's design and interpretation of the data. RL, PP, LT and BN wrote the manuscript. All authors read and approved the final manuscript.

\section{Funding}

This work was financially supported by the European Union through the funding programme Horizon 2020 (Performfish-727610) and the Ministerio de Economía, Industria y Competitividad of Spain (BIO2017-82851-C3-2-R). Raquel Lama and Patricia Pereiro wish to thank the Axencia Galega de Innovación (GAIN, Xunta de Galicia) for their predoctoral (IN606A-2017/011) and postdoctoral (IN606B-2018/010) contracts, respectively. Our laboratory is funded by EU Feder Programa Interreg España-Portugal OPE01833 and IN607B 2019/01 from the Consellería de Economía, Emprego e Industria (GAIN), Xunta de Galicia.

\section{Availability of data and materials}

The read sequences were deposited in the NCBI Sequence Read Archive (SRA) under accession number PRJNA589774.

\section{Ethics approval and consent to participate}

All the experimental procedures were reviewed and approved by the CSIC National Committee on Bioethics under approval number ES360570202001/16/FUN01/PAT.05/tipoE/BNG.

\section{Competing interests}

The authors declare that they have no competing interests.

\section{Author details}

${ }^{1}$ Institute of Marine Research (IIM), National Research Council (CSIC), Eduardo Cabello, 6, 36208 Vigo, Spain. ${ }^{2}$ Laboratory of Biotechnology and Aquatic Genomics, Interdisciplinary Center for Aquaculture Research (INCAR), University of Concepción, P.O. Box 160, Concepción, Chile. ${ }^{3}$ Department of Cell Biology, Physiology and Immunology, Autonomous University of Barcelona, 08193 Barcelona, Spain.

Received: 27 January 2020 Accepted: 16 April 2020

Published online: 12 May 2020

\section{References}

1. FAO (2005-2019) Cultured aquatic species information programme: Dicentrarchus labrax. FAO fisheries and aquaculture Department

2. Munday BL, Kwang J, Moody N (2002) Betanodavirus infections of teleost fish: a review. J Fish Dis 25:127-142

3. Nishizawa T, Furuhashi M, Nagai T, Nakai T, Muroga K (1997) Genomic classification of fish nodaviruses by molecular phylogenetic analysis of the coat protein gene. Appl Environ Microbiol 63:1633-1636

4. Doan QK, Vandeputte M, Chatain B, Morin T, Allal F (2017) Viral encephalopathy and retinopathy in aquaculture: a review. J Fish Dis 40:717-742 
5. Lu MW, Ngou FH, Chao YM, Lai YS, Chen NY, Lee FY, Chiou PP (2012) Transcriptome characterization and gene expression of Epinephelus spp in endoplasmic reticulum stress-related pathway during betanodavirus infection in vitro. Genomics 13:651

6. Liu P, Wang L, Kwang J, Yue GH, Wong SM (2016) Transcriptome analysis of genes responding to NNV infection in Asian seabass epithelial cells. Fish Shellfish Immunol 54:342-352

7. Chaves-Pozo E, Valero Y, Esteve-Codina A, Gómez-Garrido J, Dabad M, Alioto T, Meseguer J, Esteban MA, Cuesta A (2017) Innate cell-mediated cytotoxic activity of European sea bass leucocytes against nodavirusinfected cells: a functional and RNA-seq study. Sci Rep 7:15396

8. Chen W, Yi L, Feng S, Liu X, Asim M, Zhou Y, Lan J, Jiang S, Tu J, Lin L (2017) Transcriptomic profiles of striped snakehead fish cells $(\mathrm{SSN}-1)$ infected with red-spotted grouper nervous necrosis virus (RGNNV) with an emphasis on apoptosis pathway. Fish Shellfish Immunol 60:346-354

9. Chaves-Pozo E, Bandín I, Olveira JG, Esteve-Codina A, Gómez-Garrido J, Dabad M, Alioto T, Esteban MÁ, Cuesta A (2019) European sea bass brain DLB-1 cell line is susceptible to nodavirus: a transcriptomic study. Fish Shellfish Immunol 1:14-24

10. Kim JO, Kim JO, Kim WS, Oh MJ (2017) Characterization of the transcriptome and gene expression of brain tissue in Sevenband gouper (Hyporthodus septemfasciatus) in response to NNV infection. Genes 8:E31

11. Labella AM, Garcia-Rosado E, Bandín I, Dopazo CP, Castro D, Alonso MC, Borrego JJ (2018) Transcriptomic profiles of Senegalese sole infected with nervous necrosis virus reassortants presenting different degree of virulence. Front Immunol 9:1626

12. Tso CH, Lu MW (2018) Transcriptome profiling analysis of grouper during nervous necrosis virus persistent infection. Fish Shellfish Immunol 76:224-232

13. Wang L, Tian Y, Cheng M, Li Z, Li S, Wu Y, Zhang J, Ma W, Li W, Pang Z, Zhai $J$ (2019) Transcriptome comparative analysis of immune tissues from asymptomatic and diseased Epinephelus moara naturally infected with nervous necrosis virus. Fish Shellfish Immunol 93:99-107

14. Poisa-Beiro L, Dios S, Montes A, Aranguren R, Figueras A, Novoa B (2008) Nodavirus increases the expression of $\mathrm{Mx}$ and inflammatory cytokines in fish brain. Mol Immunol 45:218-225

15. Poisa-Beiro L, Dios S, Ahmed H, Vasta GR, Martínez-López A, Estepa A, Alonso-Gutiérrez J, Figueras A, Novoa B (2009) Nodavirus infection of sea bass (Dicentrarchus labrax) induces up-regulation of galectin-1 expression with potential anti-inflammatory activity. J Immunol 183:6600-6611

16. Sarropoulou E, Sepulcre P, Poisa-Beiro L, Mulero V, Meseguer J, Figueras A, Novoa B, Terzoglou V, Reinhardt R, Magoulas A, Kotoulas G (2009) Profiling of infection specific mRNA transcripts of the European seabass Dicentrarchus labrax. BMC Genomics 10:157

17. Scapigliati G, Buonocore F, Randelli E, Casani D, Meloni S, Zarletti G, Tiberi M, Pietretti D, Boschi I, Manchado M, Martin-Antonio B, JimenezCantizano R, Bovo G, Borghesan F, Lorenzen N, Einer-Jensen K, Adams S, Thompson K, Alonso C, Bejar J, Cano I, Borrego JJ, Alvarez MC (2010) Cellular and molecular immune responses of the sea bass (Dicentrarchus labrax) experimentally infected with betanodavirus. Fish Shellfish Immunol 28:303

18. Chaves-Pozo E, Guardiola FA, Meseguer J, Esteban MA, Cuesta A (2012) Nodavirus infection induces a great innate cell-mediated cytotoxic activity in resistant, gilthead seabream, and susceptible, European sea bass, teleost fish. Fish Shellfish Immunol 33:1159-1166

19. Novel P, Fernandez-Trujillo MA, Gallardo-Galvez JB, Cano I, Manchado M, Buonocore F, Randelli E, Scapigliati G, Alvarez MC, Bejar J (2013) Two Mx genes identified in European sea bass (Dicentrarchus labrax) respond differently to VNNV infection. Vet Immunol Immunopathol 153:240-248

20. Valero Y, Morcillo P, Meseguer J, Buonocore F, Esteban MA, Chaves-Pozo E, Cuesta A (2015) Characterization of the interferon pathway in the teleost fish gonad against the vertically transmitted nervous necrosis virus. J Gen Virol 96:2176-2187

21. Buonocore F, Randelli E, Tranfa P, Scapigliati G (2012) A CD83-like molecule in sea bass (Dicentrarchus labrax): molecular characterization and modulation by viral and bacterial infection. Fish Shellfish Immunol $32: 1179-1184$

22. Buonocore F, Stocchi V, Nunez-Ortiz N, Randelli E, Gerdol M, Pallavicini A, Facchiano A, Bernini C, Guerra L, Scapigliati G, Picchietti S (2017) Immunoglobulin T from sea bass (Dicentrarchus labrax L.): molecular characterization, tissue localization and expression after nodavirus infection. BMC Mol Biol 18:8

23. Tort $L$ (2011) Stress and immune modulation in fish. Dev Comp Immunol 35:1366-1375

24. Bovo G, Nishizawa T, Maltese C, Borghesan F, Mutinelli F, Montesi F, De Mas S (1999) Viral encephalopathy and retinopathy of farmed marine fish species in Italy. Virus Res 63:143-146

25. Reed $\sqcup$, Müench $H$ (1938) A simple method of estimating fifty per cent end-points. Am J Hyg 27:493-497

26. Pfaffl MW (2001) A new mathematical model for relative quantification in real-time RT-PCR. Nucleic Acids Res 29:2002-2007

27. Kuo HC, Wang TY, Chen PP, Chen YM, Chuang HC, Chen TY (2011) Realtime quantitative PCR assay for monitoring of nervous necrosis virus infection in grouper aquaculture. J Clin Microbiol 49:1090-1096

28. Morgan JD, Iwama GK (1996) Cortisol-induced changes in oxygen consumption and ionic regulation in coastal cutthroat trout (Oncorhynchus clarki clarki) parr. Fish Physiol Biochem 15:385-394

29. Dong XX, Wang Y, Qin ZH (2009) Molecular mechanisms of excitotoxicity and their relevance to pathogenesis of neurodegenerative diseases. Acta Pharmacol Sin 30:379-387

30. Mennerich D, Kelokumpu S, Kietzmann T (2019) Hypoxia and reactive oxygen species as modulators of endoplasmic reticulum and Golgy homeostasis. Antioxid Redox Signal 30:113-137

31. Forrester JV, McMenamin PG, Dando SJ (2018) CNS infection and immune privilege. Nat Rev Neurosci 19:655-671

32. Khansari AR, Parra D, Reyes-López FE, Tort L (2017) Modulatory in vitro effect of stress hormones on the cytokine response of rainbow trout and gilthead sea bream head kidney stimulated with Vibrio anguillarum bacterin. Fish Shellfish Immunol 70:736-749

33. Benhar I, London A, Schwartz M (2012) The privileged immunity of immune privileged organs: the case of the eye. Front Immunol 3:296

34. Dios S, Poisa-Beiro L, Figueras A, Novoa B (2007) Suppression subtraction hybridization ( $\mathrm{SSH}$ ) and macroarray techniques reveal differential gene expression profiles in brain of sea bream infected with nodavirus. Mol Immunol 44:2195-2204

35. Gorissen M, Flik G (2016) The endocrinology of the stress response in fish: an adaptation-physiological view. In: Schreck CB, Tort L, Farrell AP, Brauner CJ (eds) Biology of stress in fish-fish physiology, vol 35. Academic Press, London

36. Barton BA, Iwama GK (1991) Physiological changes in fish from stress in aquaculture with emphasis on the response and effects of corticosteroids. Ann Rev Fish Dis 1:13-26

37. Heisler LK, Pronchuk N, Nonogaki K, Zhou L, Raber J, Tung L, Yeo GS, O'Rahilly S, Colmers WF, Elmquist JK, Tecott LH (2007) Serotonin activates the hypothalamic-pituitary-adrenal axis via serotonin $2 \mathrm{C}$ receptor stimulation. J Neurosci 27:6956-6964

38. Levy BH, Tasker JG (2012) Synaptic regulation of the hypothalamic-pituitary-adrenal axis and its modulation by glucocorticoids and stress. Front Cell Neurosci 6:24

39. Liu X, Khansari A, Teles M, Martínez-Rodríguez G, Zhang Y, Mancera JM, Reyes-López FE, Tort L (2019) Brain and pituitary response to vaccination in gilthead seabream (Sparus aurata L.). Front Physiol 10:717

40. Schreck CB, Tort $L$ (2016) The concept of stress in fish. In: Schreck CB, Tort $\mathrm{L}$, Farrell AP, Brauner CJ (eds) Biology of stress in fish-fish physiology, vol 35. Academic Press, London

41. Yada T, Nakanishi T (2002) Interaction between endocrine and immune systems in fish. Int Rev Cytol 220:35-92

42. Pijanowski L, Jurecka P, Irnazarow I, Kepka M, Szwejser E, Verburg-van Kemenade BML, Chadzinska M (2015) Activity of the hypothalamuspituitary-interrenal axis (HPI axis) and immune response in carp lines with different susceptibility to disease. Fish Physiol Biochem 41:1261-1278

43. Grove S, Johansen R, Reitan LJ, Press CM, Dannevig BH (2006) Quantitative investigation of antigen and immune response in nervous and lymphoid tissues of Atlantic halibut (Hippoglossus hippoglossus) challenged with nodavirus. Fish Shellfish Immunol 21:525-539

44. López-Muñoz A, Sepulcre MP, García-Moreno D, Fuentes I, Béjar J, Manchado M, Álvarez MC, Meseguer J, Mulero V (2012) Viral nervous necrosis virus persistently replicates in the central nervous system of asymptomatic gilthead seabream and promotes a transient inflammatory response followed by the infiltration of Ig $\mathrm{M}+\mathrm{B}$ lymphocytes. Dev Comp Immunol 37:429-437 
45. Piazzon MC, Galindo-Villegas J, Pereiro P, Estensoro I, Calduch-Giner JA, Gómez-Casado E, Novoa B, Mulero V, Sitjà-Bobadilla A, Pérez-Sánchez J (2016) Differential modulation of IgT and IgM upon parasitic, bacterial, viral, and dietary challenges in a perciform fish. Front Immunol 7:637

46. Parra D, Reyes-Lopez FE, Tort L (2015) Mucosal immunity and B cells in teleosts: effect of vaccination and stress. Front Immunol 6:354

47. Yada T, Nagae M, Moriyama S, Azuma T (1999) Effects of prolactin and growth hormone on plasma immunoglobulin M levels of hypophysectomized rainbow trout, Oncorhynchus mykiss. Gen Comp Endocrinol 115:46-52

48. Chen NC, Yoshimura M, Guan HH, Wang TY, Misumi Y, Lin CC, Chuankhayan P, Nakagawa A, Chan SI, Tsukihara T, Chen TY, Chen C. (2015) Crystal structures of a piscine betanodavirus: mechanisms of capsid assembly and viral infection. PLoS Pathog 11:e1005203

49. Jang $S$, Oh D, Lee $Y$, Hosy E, Shin H, van Riesen C, Whitcomb D, Warburton JM, Jo J, Kim D, Kim SG, Um SM, Kwon SK, Kim MH, Roh JD, Woo J, Jun H, Lee D, Mah W, Kim H, Kaang BK, Cho K, Rhee JS, Choquet D, Kim E (2016) Synaptic adhesion molecule IgSF11 regulates synaptic transmission and plasticity. Nat Neurosci 19:84-93

50. Chen J, Kaul S, Simons SS Jr (2002) Structure/activity elements of the multifunctional protein, GMEB-1. Characterization of domains relevant for the modulation of glucocorticoid receptor transactivation properties. J Biol Chem 277:22053-22062

51. Plotsky PM, Otto S, Sutton S (1987) Neurotransmitter modulation of corticotropin releasing factor secretion into the hypophysial-portal circulation. Life Sci 41:1311-1317

52. Schulz JB, Matthews RT, Jenkins BG, Ferrante RJ, Siwek D, Henshaw DR, Cipolloni PB, Mecocci P, Kowall NW, Rosen BR (1995) Blockade of neuronal nitric oxide synthase protects against excitotoxicity in vivo. J Neurosci 15:8419-8429
53. Schonbrunn A, Koch BD (1987) Mechanisms by which somatostatin inhibits pituitary hormone release. In: Reichlin S (ed) somatostatin. Springer, Boston

54. Costanza M, Binart N, Steinman L, Pedotti R (2015) Prolactin: a versatile regulator of inflammation and autoimmune pathology. Autoimmun Rev 14:223-230

55. Rivero-Segura NA, Flores-Soto E, García de la Cadena S, Coronado-Mares I, Gomez-Verjan JC, Ferreira DG, Cabrera-Reyes EA, Lopes LV, Massieu L, Cerbón M (2017) Prolactin-induced neuroprotection against glutamate excitotoxicity is mediated by the reduction of [Ca2 + ]i overload and NF-kB activation. PLoS One 12:e0176910

56. Gonzalez C, Corbacho AM, Eiserich JP, Garcia C, Lopez-Barrera F, MoralesTlalpan V, Barajas-Espinosa A, Diaz-Muñoz M, Rubio R, Lin SH, Martinez de la Escalera G, Clapp C (2004) 16K-Prolactin inhibits activation of endothelial nitric oxide synthase, intracellular calcium mobilization, and endothelium-dependent vasorelaxation. Endocrinology 145:5714-5722

57. Webster Jl, Sternberg EM (2004) Role of the hypothalamic-pituitary-adrenal axis, glucocorticoids and glucocorticoid receptors in toxic sequelae of exposure to bacterial and viral products. J Endocrinol 181:207-221

58. Silverman MN, Pearce BD, Biron CA, Miller AH (2005) Immune modulation of the hypothalamic-pituitary-adrenal (HPA) axis during viral infection. Viral Immunol 18:41-78

59. Castric J, Thiéry R, Jeffroy J, de Kinkelin P, Raymond J (2001) Sea bream Sparus aurata, an asymptomatic contagious fish host for nodavirus. Dis Aquat Organ 47:33-38

\section{Publisher's Note}

Springer Nature remains neutral with regard to jurisdictional claims in published maps and institutional affiliations.
Ready to submit your research? Choose BMC and benefit from:

- fast, convenient online submission

- thorough peer review by experienced researchers in your field

- rapid publication on acceptance

- support for research data, including large and complex data types

- gold Open Access which fosters wider collaboration and increased citations

- maximum visibility for your research: over 100M website views per year

At BMC, research is always in progress.

Learn more biomedcentral.com/submissions 